University of Chicago Law School

Chicago Unbound

Journal Articles

Faculty Scholarship

1992

\title{
The Politics of Women's Wrongs and the Bill of 'Rights': A \\ Bicentennial Perspective
}

Mary E. Becker

Follow this and additional works at: https://chicagounbound.uchicago.edu/journal_articles

Part of the Law Commons

\section{Recommended Citation}

Mary E. Becker, "The Politics of Women's Wrongs and the Bill of 'Rights': A Bicentennial Perspective," 59 University of Chicago Law Review 453 (1992).

This Article is brought to you for free and open access by the Faculty Scholarship at Chicago Unbound. It has been accepted for inclusion in Journal Articles by an authorized administrator of Chicago Unbound. For more information, please contact unbound@law.uchicago.edu. 


\title{
The Politics of Women's Wrongs and the Bill of "Rights": A Bicentennial Perspective
}

\author{
Mary E. Becker ${ }^{\dagger}$
}

The language of the Bill of Rights is almost entirely gender neutral and its provisions have always applied to some women. ${ }^{1}$ But free white men of property designed the Bill of Rights in a political process from which they excluded most Americans and all women. Not surprisingly, the Bill of Rights served and serves the interests of such men better than the interests of others.

Legal constitutional literature, whether from the right or the left, tends to be celebratory rather than critical. ${ }^{2}$ But in looking back on the Bill of Rights during this bicentennial year, women and many men outside the propertied white male class should be ambivalent. In this Article, I assess the Bill of Rights from the per-

† Professor of Law, The University of Chicago Law School. This Article is the written version of the Katz Lecture given at The University of Chicago Law School on October 24, 1991. I thank Pauline Bart, Cynthia Bowman, Jill Fosse, Marcella David, Rochelle Dreyfus, Laurie Feldman, Stephen Gilles, Mary Ann Glendon, Wendy Gordon, Hendrick Hartog, Lynne Henderson, Jennifer Hertz, Linda Hirschman, Elena Kagan, Linda Kerber, Larry Kramer, Norval Morris, Judith Resnik, Carol Rose, Vicki Schultz, Kenneth Simmons, Geoffrey Stone, Cass Sunstein, Nadine Taub, Morrison Torrey, Robin West, John Wiley, and workshop participants at the Chicago Feminist Colloquium, UCLA Law School, Emory Law School, University of Miami Law School, NYU Law School, Northwestern Law School, and the University of Wisconsin Law School for helpful comments on earlier drafts and Paul Bryan, Jennifer Hertz, Elizabeth Rosenblatt, William Schwesig and Charles Ten Brink for research and other assistance. Research support was provided by the Russell Baker Scholars Fund and the Russell J. Parsons Faculty Research Fund of the University of Chicago and by the Morton C. Seely Fund and the Jerome S. Weiss Faculty Research Fund.

1 The Bill of Rights is almost entirely free of gendered language. It speaks repeatedly of "person" or "people." The Fifth Amendment contains one "himself" and the Sixth Amendment one "him" and two "his's." Thus, one has the right not to be "compelled in any criminal case to be a witness against himself," US Const, Amend V (emphasis added); the right of the criminal defendant "to be confronted with the witnesses against him; to have compulsory process for obtaining witnesses in his favor, and to have the Assistance of Counsel for his defense," US Const, Amend VI (emphasis added). But the clauses containing these references were understood as applying to "free" women from the first.

${ }^{2}$ See, for example, John Paul Stevens, The Bill of Rights: A Century of Progress, $59 \mathrm{U}$ Chi L Rev 13 (1992); Charles Fried, The New First Amendment Jurisprudence: $A$ Threat to Liberty, 59 U Chi L Rev 225 (1992); Cass R. Sunstein, Free Speech Now, 59 U Chi L Rev 255 (1992); Michael W. McConnell, Religious Freedom at a Crossroads, 59 U Chi L Rev 115 (1992); and Kathleen M. Sullivan, Religion and Liberal Democracy, 59 U Chi L Rev 195 (1992). 
spective of women and other outsiders, with special emphasis on its continuing impact on women's political participation. I offer three kinds of criticisms in discussing specific clauses.

First, and most important, I make a point that is not normative or prescriptive but merely critical: the Bill of Rights does less to solve the problems of women and nonpropertied men than to solve the problems of men of property, especially white men of property. Some clauses, such as the Fifth Amendment right to "property," originally did not help most women, or helped only trivially, or had vastly different meanings for women and men. Often this disparity continues. Some provisions overlook much more serious problems for women than the problems they address. Consider, for example, women's Fourth Amendment right "to be secure in their persons, houses, papers, and effects against unreasonable [governmental] searches and seizures." 3 The Fourth Amendment neither gives women security in their homes from husbands nor ensures that government treat marital rape like other rapes and assaults. Indeed, at the time the Fourth Amendment was adopted, and in many jurisdictions today, husbands and lovers could and can rape "their" women without criminal consequences.

Some provisions operate differently for women and men in the sense that they perpetuate women's subordinate status. Although many historical inequities would have persisted without the Bill of Rights, the Bill magnifies these inequities. For example, the Religion Clauses permit substantial subsidies from government to mostly-patriarchal religious organizations-organizations that continue to be important socializing institutions for children.

Second, although the Bill of Rights may not cause a given problem, it sometimes impedes legislative reform. We revere the Bill of Rights; ${ }^{4}$ its invocation legitimates the status quo. For example, the Second Amendment assists the National Rifle Association in preventing stringent federal gun control legislation. Thus, although gun control might be good for women, and is favored by most women, ${ }^{5}$ the Second Amendment impedes its adoption.

My third point concerns politics. Several provisions of the Bill of Rights have continuing political effects, impeding women's effec-

\footnotetext{
${ }^{3}$ US Const, Amend IV.

4 See, for example, Hendrik Hartog, The Constitution of Aspiration and "The Rights That Belong to Us All", 74 J Amer Hist 1013 (1987).

- Katherine M. Jamieson and Timothy J. Flanagan, eds, Sourcebook of Criminal Justice Statistics 110, Table 2.43 (US Dept of Justice, 1987).
} 
tive political participation today. Consider, for example, Buckley $v$ Valeo, which held unconstitutional spending limits on individuals directly engaging in political speech, thus constitutionalizing the right of the rich to participate in the political process more effectively than the poor. ${ }^{6}$ And women are, of course, disproportionately poor. ${ }^{7}$

More fundamentally, the Bill of Rights is inadequate in guaranteeing women the exercise of governmental power. Given that women were excluded from the process that produced the Bill of Rights and that few women occupy high government positions today, we should question the legitimacy of our purported democracy. Surely we would question whether another government was truly democratic if a majority group, other than women, had never held the top executive position and comprised only six percent of the national legislature. ${ }^{8}$ Only six percent of governors are women. ${ }^{9}$ Women hold only eighteen percent of state-wide elective offices. ${ }^{10}$ Women occupy only 18.1 percent of state legislative seats. ${ }^{11}$

Women are similarly under-represented in judicial positions at the state and federal levels. At the state level, only 2.8 percent of the law-trained trial court judges are women; 5.5 percent of intermediate appellate state judges are women. ${ }^{12}$ On state supreme courts, 5.89 percent of justices are women; 0.56 percent are minority women. ${ }^{13}$ At the federal level, women comprise only 4.07 percent of administrative law judges; seven percent of district court judges; eight percent of appellate judges; and 11.11 percent of the

- 424 US 1, 58-59 (1976).

7 See, for example, 163 Current Population Reports: Consumer Income: Poverty in the United States: 1987, 118-19 (US Bureau of the Census, 1989).

B See Center for the American Woman and Politics (CAWP), Fact Sheet: Women in Elective Office 1991, Table 2 (Eagleton Institute, 1991) (on file with U Chi L Rev).

- The World Almanac and Book of Facts 1992 596-99 (World Almanac, 1991).

10 CAWP, Fact Sheet: Statewide Elective Executive Women 19911 (Eagleton Institute, 1991) (on file with U Chi L Rev).

"Id.

12 Telephone conversation with Dixie Noble, National Association of Women Judges, Williamsburg, Virginia (Oct 3, 1991) (notes on file with U Chi L Rev). This data was current as of the date of the call for the intermediate and appellate state courts. The data on trial court judges is from 1985. I have not been able to find data on minority judges in other categories.

${ }^{13}$ Id. 
Supreme Court. No women serve as senior appellate judges and less than two percent of the senior trial judges are women. ${ }^{14}$

Two points recur in my criticisms of various clauses. The Bill of Rights incorporates a private-public split ${ }^{15}$ with only negative rights under a limited government. As a result, women's activities and concerns-from economic rights to religion-seem beyond the proper scope of government. That women are poorer than, and subordinate to, men appears "natural" and pre-political. Because of the private-public split, the Bill of Rights protects a number of institutions that are not entirely good for women from governmental interference and effective reform, such as the media. Because the Bill of Rights incorporates only "negative" rights, it includes no provision guaranteeing, or even defining as an important concern of national government, the economic and educational rights so important to women as caretakers. Indeed, women in the United States have fewer economic and educational supports than in any other North Atlantic nation.

To a large extent, my criticisms could apply to any written set of cryptic, abstract, and negative rights enforced by judges. Any such scheme will better protect the powerful against government action harmful to their interests than the less powerful, who need protection against the powerful as well as against the government. In part, this is because abstract rights enforced by judges, regardless of their wording, are unlikely to make radical changes in the distribution of power and resources. ${ }^{16}$ The less powerful need many concrete, positive rights. These rights require detailed implementation schemes and the expenditure of funds. Judges are not likely to order either when enforcing abstract clauses. For example, no matter how a constitution states its equality provision, it is unlikely that the provision would lead judges to restructure the social security system so as to provide equivalent old-age security to breadwinners and homemakers. ${ }^{17}$

${ }^{14}$ Id. For discussions of this problem, see Carl Tobias, The Federal Judiciary Engendered, 5 Wis Women's L J 123 (1990); Judith Resnik, "Naturally" Without Gender: Women, Jurisdiction and the Federal Courts, 66 NYU L Rev (forthcoming 1992).

${ }^{15}$ For a discussion of the inconsistencies in the way we look at the public-private split, see Frances E. Olsen, The Family and the Market: A Study of Ideology and Legal Reform, 96 Harv L Rev 1497 (1983).

${ }^{16}$ See, for example, Gerald N. Rosenberg, The Hollow Hope: Can Courts Bring About Social Change? (Chicago, 1991); Mary E. Becker, Prince Charming: Abstract Equality, 1987 S Ct Rev 201.

${ }^{17}$ See Mary E. Becker, Obscuring the Struggle: Sex Discrimination, Social Security, and Stone, Seidman, Sunstein \& Tushnet's Constitutional Law, 89 Colum L Rev 264, 271 85 (1989). 
We cannot, therefore, expect a piece of paper to produce justice for women or other disadvantaged groups. ${ }^{18}$ I nevertheless suggest a number of ways in which the Bill of Rights could be improved through interpretation or amendment. For example, courts could redefine, or legislatures amend, the Religion Clauses of the First Amendment to prohibit government subsidies to religions that close the ministry to women. Courts could read the Free Speech Clause of the First Amendment to allow content-based governmental regulation of some sexist and racist speech, or subsidies for nonsexist speech.

Some of my points focus on the underclass, rather than women as such. It is impossible to separate the interests of women from those of their class and race. When, for example, justice is denied the urban underclass in the criminal "justice" system, women inevitably suffer even though most of those caught directly in the system are men. Women suffer the destruction of their communities as well as the destruction of the men and boys who are, or might have been, in their lives.

In the Conclusion, I make several general points not directed at specific provisions of the Bill of Rights. An ideal Constitution or Bill of Rights would contain a substantive sex equality provision. At a minimum, such a provision could require judges to take into account detrimental impact on women when approaching other constitutional provisions as well as legislation and other governmental action. ${ }^{19}$

In the Conclusion, I address more basic structural problems with the Constitution and the Bill of Rights. First, I note that our constitutional structure, with its emphasis on individual rights conceived in absolutist and negative terms, particularly property rights, contributes to a culture in which the kinds of economic rights women need are difficult to achieve. Mary Ann Glendon makes this point in her most recent book. ${ }^{20}$ Absolutist individual rights are almost inevitably negative limits on government. Giving constitutional sanctity to negative rights only, with a central role for property rights, reinforces American faith in rugged individualism which is so incompatible with the needs of children and their caretakers.

18 See, for example, Rosenberg, The Hollow Hope at 10-13 (cited in note 16): Becker, 1987 S Ct Rev 201 (cited in note 16).

${ }^{18}$ See note 301 and accompanying text.

${ }^{20}$ Mary Ann Glendon, Rights Talk: The Impoverishment of Political Discourse 14, 2425 (Free Press, 1991). 
I also discuss some of the ways in which our constitutional structure is countermajoritarian. The Framers deliberately devised a government that would protect the propertied minority from oppression by the propertyless majority. ${ }^{21}$ We should see it as a problem of democracy that, to date, women have not exercised their share of governmental power. I suggest that other governmental structures and electoral systems might be more democratic. ${ }^{22}$

In as many sections, I discuss seven clauses or sets of clauses in the Bill of Rights: the Religion Clauses ${ }^{23}$ and Free Speech Clause $^{24}$ of the First Amendment; the right to bear arms of the Second Amendment; ${ }^{25}$ protections against misuse of the criminal justice system in the Fourth, Fifth, and Sixth Amendments; ${ }^{26}$ the right to be secure in one's home under the Fourth Amendment; ${ }^{27}$ the property right of the Fifth Amendment;; and the Due Process right of the Fifth Amendment, together with the jury provisions of the Sixth and Seventh Amendments. ${ }^{29} \mathrm{I}$ begin with the first two clauses of the First Amendment, which "guarantee" freedom of religion. I discuss the religion clauses in greater depth than the others because there have been so few explorations in the legal literature of the problems religion poses for women. ${ }^{30}$

\section{Religious Freedom}

The Bill of Rights begins with the First Amendment's Religion Clauses: "Congress shall make no law respecting an establishment of religion, or prohibiting the free exercise thereof." criticisms apply to both of these provisions. Religious freedom has meant, and means, vastly different things to women and men. In a number of ways this freedom secures to men rights superior to

21 Jennifer Nedelsky, Private Property and the Limits of American Constitutionalism: The Madisonian Framework and Its Legacy 220-22 (Chicago, 1990).

${ }^{22}$ See notes 293-300 and accompanying text.

${ }^{23}$ See Section I.

${ }^{24}$ See Section II.

${ }^{25}$ See Section III.

${ }^{26}$ See Section IV.

${ }^{27}$ See Section V.

28 See Section VI.

${ }^{29}$ See Section VII.

so For examples of articles that do discuss the patriarchal nature of religion, see Judith C. Miles, Beyond Bob Jones: Toward the Elimination of Governmental Subsidy of Discrimination by Religious Institutions, 8 Harv Women's L J 31 (1985); Kathleen A. McDonald, Battered Wives, Religion, and Law: An Interdisciplinary Approach, 2 Yale $\mathrm{J} \mathrm{L}$ and Feminism 251 (1990); Judith Resnik, On the Bias, Feminist Reconsiderations of the Aspirations of Our Judges, 61 S Cal L Rev 1877, 1918-21 (1988).

s1 US Const, Amend I. 
those secured to women. As I discuss below, religion perpetuates and reinforces women's subordination, and religious freedom impedes reform. The Religion Clauses allow substantial government subsidies of religion, such as exemptions from income and property taxes and awards of government contracts, thus assisting religion in perpetuating the subordination of women. Religious freedom also impedes women's effective political participation.

I divide the discussion of religion into four parts. I begin with a discussion of the ways in which religious practices and doctrine contribute to traditional attitudes towards women and their appropriate roles. Next, I discuss positive aspects of the relationship between religion and women: religion has often empowered women and has responded to and reflected the beliefs and values of women, who are, in general, more religious than men. Third, I consider empirical evidence on the relationship between religion and women's subordinate status. This evidence indicates that, despite the positive potential of religion and the ways in which women shape religion, mainstream Christian religions in the United States tend to contribute to women's subordinate status and to retard women's ability to participate fully and effectively in political life. I discuss several examples of current governmental subsidies of mostly-patriarchal religion. I conclude the Section by suggesting that the Religion Clauses be interpreted or amended to minimize their countermajoritarian effect while still preserving the positive potential of religion.

\section{A. Religion and Patriarchy}

The religious freedom clauses do not have the same meaning for women and men. For the Framers, the social reality of religious freedom meant their own freedom and the freedom of other men of their race and class to develop, govern, and control religion free of state interference. Even men of other races and classes could be religious leaders. For example, prior, even, to emancipation separate black churches developed led by black preachers. ${ }^{32}$ These separate churches laid the foundation for an autonomous AfricanAmerican Christianity. ${ }^{33}$

Religious freedom has not had this meaning for women. Religious leaders have been overwhelmingly male from the time the

32 See, for example, Eugene D. Genovese, Roll, Jordan, Roll: The World the Slaves Made 255-79 (Pantheon, 1974).

${ }^{33}$ Id at 280. 
Bill - of Rights was passed until the present day. Many religious groups, including Mormons, Roman Catholics, and Orthodox Jews, still close the ministry to women. Other groups allow female ministers, but women still lead those groups in relatively low numbers, especially in the organizational hierarchy or at the head of large and important congregations. ${ }^{34}$

Male control of religious leadership has a number of negative effects. Only men are able to use positions as religious leaders to rise in the social hierarchy and to become leaders in their communities. The absence of women in leadership positions suggests to younger women and girls that women are not capable of leadership. Most important, because mainstream religious leadership has been and remains so dominated by men, mainstream religion inevitably incorporates male perspectives and bias against women. As one (male) student of comparative religion put it, "regardless of what a religion teaches about the status of women, or what its attitudes toward sex might be, if women are excluded from the institutions. and positions that influence society, a general misogynism seems to result." 35 Religions thus contribute to women's subordinate status, not only within religious communities' hierarchies, but also in the broader culture.

At the time the Bill of Rights was passed, mainstream American religions taught the subordination of women openly and without embarrassment. For example, the Reverend Amos Chase described women's divinely ordained position of inferiority in a funeral sermon in Litchfield, Connecticut in 1791:

A woman of fine feelings cannot be insensible that her constitutional condition is secondary and dependant [sic] among men. Nor can she long want conviction that the sure way to avoid any evil (to the thus dependant) [sic] is to yield the front of battle to a hardier sex. ${ }^{36}$

Religion was often used to legitimate the use of the state's power to enforce women's inferior social position. For example, in

\footnotetext{
34 See, for example, Keith A. Roberts, Religion in Sociological Perspective 291-94 (Wadsworth, 2d ed 1990).

${ }^{35}$ Vern L. Bullough, The Subordinate Sex: A History of Attitudes Toward Women 134 (Illinois, 1973).

${ }^{36}$ Amos Chase, On Female Excellence, or a Discourse in which Good Character in Women is Described, Occasioned by the Death of his Wife 12 (delivered at Litchfield, March 6, 1791), as quoted in Nancy Falik Cott, In the Bonds of Womanhood: Perspectives on Female Experience and Consciousness in New England 1780-1830 99 (1974) (unpublished Ph.D. dissertation, Brandeis University (Waltham)) (on file with U Chi L Rev).
} 
Bradwell $v$ Illinois, the Supreme Court upheld a statute barring women from the practice of law, with three concurring justices using divine law to justify a man-made law by which men gave themselves a monopoly in the practice of law. ${ }^{37}$

Today, mainstream religions in the United States remain patriarchal in many ways. I begin with a discussion of substantive problems with religious doctrines and practices from the perspective of women. ${ }^{38}$ The Religion Clauses have given men a comparatively greater ability to develop meaning, values, and morality based on an authority independent of government and made in their image. Although religion means much to women, it has not meant this.

1. Creation, male gods, and Eve.

All mainstream religious traditions in the United States replace the wonder of women's reproductive power with stories of creation by a male god. ${ }^{39}$ In one of the two creation myths in Genesis, God created Eve out of Adam's rib to be his partner (rather than a being with her own purposes). ${ }^{40}$ Eve tempts Adam and her reproductive power becomes a punishment for sin in the story of the fall. ${ }^{41}$ Because of her sin, God declares Adam her master. ${ }^{42}$ Christianity adds, as a prerequisite to true life, rebirth through redemption by a male god. ${ }^{43}$

Although there is an occasional use of female imagery in the Judeo-Christian tradition-in the Wisdom literature, for example ${ }^{44}$ - the gods of that tradition are overwhelmingly male. The Christian "God the Father" is the ultimate male warrior: utterly

${ }^{37} 83$ US (16 Wallace) 130, 132, 139 (1872).

${ }^{38}$ I have organized the discussion in the subsection in seven points, some of which apply to Jews and Christians, others of which apply only to Christians. Because most religious Americans are Jews or Christians, and because my space is limited, I examine only these traditions.

${ }^{30}$ Beverly Wildung Harrison, Our Right to Choose: Toward a New Ethic of Abortion 60-61 (Beacon, 1983); Mary Daly, Gyn/Ecology: The Metaethics of Radical Feminism 73-89 (Beacon, 1990).

${ }^{10}$ Genesis 2:18-23 (New English Bible). A less sexist version of creation is presented in the first story of creation. See Genesis 1:26-28.

1 Genesis 3:16-19 (New English Bible):

To the Woman he said: "I will increase your labor and your groaning, and in labour you shall bear children. You shall be eager for your husband, and he shall be your master."

42 See id.

${ }^{43}$ Harrison, Our Right to Choose 59-61 (cited in note 39); Daly, Gyn/Ecology at 83-89 (cited in note 39).

" See, for example, The Wisdom of Solomon 10: 1-19 (New English Bible). 
alone and without need for others or the ability to empathize with them, the unmoved mover. ${ }^{45}$ More than the language ascribes maleness; the Old Testament God typifies the masculine warrior hero in western culture, violent and overpowering, striking down his enemies. ${ }^{46}$ Jesus is, by contrast, often very feminine, ${ }^{47}$ but his gender is clearly male. Although Mary sometimes has near-divinity status, she is a singularly passive and subservient god.

It is easy to dismiss this complaint as silly or unimportant. The effect of male gods goes unnoticed because it is so ubiquitous, and is effective because so consistent with male domination in our culture. If you look around, you will see widespread and severe under-representation of women in positions of power, as gods, in the ministry, as heroes, and as authorities, whether in religion or sports or the military or the evening news. Some of these problems are discussed elsewhere in this article. ${ }^{48}$ The cumulative effect is a double message to girls. On one level, they hear, "you're equal, you're equal, you're equal." But when they observe the world around them, on television, in their history books, in their story books, in literature or religion, girls receive a different message: "you're not, you're not, you're not." Almost exclusively, they see males as active heroes and in positions of power and honor. Not surprisingly, girls and young women have less self-esteem and confidence than boys and men. ${ }^{49}$

Men in our culture fail to appreciate the advantages of having gods in their image. But women who can imagine a female god, despite indoctrination in religions with male gods, can sense the power of such images. Someone raised in the white Judeo-Christian tradition has extreme difficulty imagining a female god. But

is For feminist insight on the vision of "God the Father" as a male figure, see Catherine Keller, From a Broken Web: Separation, Sexism and Self 38-40, 86-87 (Beacon, 1986); Carol P. Christ, Laughter of Aphrodite: Reflections on a Journey to the Goddess 93-101 (Harper \& Row, 1987); Susan Brooks Thistlethwaite, Sex, Race, and God: Christian Feminism in Black and White 109-25 (Crossroad, 1989).

${ }^{6}$ See, for example, Psalm 7:12-13 (New English Bible): "He sharpens his sword,/ strings his bow and makes it ready./He has prepared his deadly shafts and tipped his arrows with fire."

${ }^{77}$ For a discussion of the more feminine Jesus, central to the devotional life of many Christian women, white and black, see text accompanying notes 87-88.

48 See text accompanying notes $152-59,200$, for example.

49 American Association of University Women, Shortchanging Girls, Shortchanging America: A nationwide poll to assess self esteem, educational experiences, interest in math and science, and career aspirations of girls and boys ages 9-15 graph B (following p 5) (Greenberg-Lake Analysis Group, 1991) (in elementary school, girls' self-esteem is $79 \%$ of boys'; in middle school and high school, $60 \%$ (calculation from figures in graph B)). 
just a glimpse of the Goddess can be startling and empowering. ${ }^{50}$ Mainstream American religions have not offered women what they offer men: the ability as leaders to develop powerful images of gods like themselves.

2. Emphasis on family stability.

In addition, all mainstream religious traditions emphasize family stability. Inequities exist in most families today, however, where women generally work more hours a week than their husbands because of the husbands' failure to share the second shift-housework. Emphasis on family stability, at least without an equal emphasis on the need for change within families, reinforces current advantages of both power and leisure that men enjoy within families. Religion encourages women to live with the status quo rather than destabilizing it by insisting on equality. For battered women, this emphasis reinforces their tendency to think only of the needs of others" and to try to keep the "family together at all costs-even the woman's life." 52 Again, religion does not do the same thing for women and men. status.

3. Fundamentalism, orthodoxy, and women's subordinate

Today, fundamentalist and orthodox religious groups, such as fundamentalist Christians, continue to teach, explicitly or implicitly, that women should be subordinate to men. For example, fundamentalist Christians still often state overtly that wives should submit to husbands. In The Total Woman, Marabel Morgan describes the "biblical remedy for marital conflict": "wives must submit to [their] husbands' leadership in the same way [they] submit to the Lord," "citing Paul's letter to the Ephesians. ${ }^{53}$

Orthodox Jews state less explicitly that wives should submit to husbands, but orthodox belief and practice implies women's inferiority in at least four different ways. First, Judaism is phallocentric:

${ }^{\text {so }}$ Catherine Keller discusses parallels between the opening of Genesis and earlier Babylonian creation myths and concludes that the earlier Goddess is reflected in certain words in Genesis. I was thrilled (and amazed at how thrilling it was) to find such a revelation in the words I had been taught to revere as a child. See Keller, From a Broken Web at 80-88 (cited in note 45).

${ }^{52}$ Robin West, The Difference in Women's Hedonic Lives: A Phenomenological Critique of Feminist Legal Theory, 3 Wis Women's L J 81, 98 (1987).

${ }^{32}$ Lenore E. Walker, The Battered Woman 164 (Harper \& Row, 1979).

${ }^{53}$ Marabel Morgan, The Total Woman 69 (Revell, 1973) (quoting The Living Bible Ephesians 5:22 (Tyndale House, 1971)). 
a mark on the penises of baby boys symbolizes "Abraham's everlasting covenant with his god." The phallus is thus sanctified. ${ }^{54}$

Second, Jewish marriage and divorce law do not treat women and men as equals. ${ }^{55}$ In both, women are passive, men are active. In an Orthodox wedding, the bride says nothing. A divorce is something a man effects and gives to a woman; she cannot remarry unless he agrees to divorce her. Although she can demand a divorce, and he should then give it to her, among the strictly Orthodox she often has little recourse if he refuses.

Third, the obligation to worship and to study Torah, central to the lives of Orthodox men, is less important for women, though women should know enough Torah to be able to educate their children. Implicit is the message that she counts less. Indeed, for purposes of the minyan (the quorum needed for certain prayers), she does not count at all. Her husband begins the day by thanking God that he was not born a woman. (Thereby, according to the least objectionable meaning, expressing gratitude that he is called to worship God and study Torah). ${ }^{56}$

Fourth, the Jewish faith relegates women to serving others, rather than recognizing them as creatures with important spiritual lives. ${ }^{57}$ Orthodox men serve God through prayer and study. Orthodox women serve God through serving others. For very Orthodox women, much of this service consists of cooking and cleaning under circumstances made onerous by dietary laws. ${ }^{58}$

Fundamentalist religious groups encourage or require women to fulfill traditional roles, including economic dependence on husbands and serving others in the home. Yet economic dependence on individual men weakens women's position within marriage. The combination of traditional roles and fundamentalists' unusually strong emphasis (relative even to other mainstream religious groups) on family stability lessens fundamentalist women's ability to object to traditional relationships between the sexes. Again, the

st Batya Bauman, Women-identified Women in Male-identified Judaism, in Susannah Heschel, ed, On Being a Jewish Feminist: A Reader 88, 91 (Schocken, 1983).

${ }^{s 5}$ Saul Berman, The Status of Women in Halakhic Judaism, in Elizabeth Koltun, ed, The Jewish Woman: New Perspectives 114, 115 (Schocken, 1976).

s6 Thena Kendall, Memories of an Orthodox Youth in Heschel, ed, On Being a Jewish Feminist: $A$ Reader 96, 97-98 (cited in note 54).

${ }^{87}$ Berman, The Status of Women in Halakhic Judaism at 116 (cited in note 55).

${ }^{58}$ Kendall, Memories of an Orthodox Youth (cited in note 56). At the same time giving spiritual significance to women's work and the way it is done is in some ways positive, according importance and value to women. 
main point is that religion does not offer women what it offers men.

4. The core of Christianity: forgiving and suffering.

All strands of Christianity urge forgiving. Christianity teaches that the virtuous person forgives even the unpardonable. Quoting Matthew 18:22, Marabel Morgan advises wives to forgive "seventy times seven." Christianity also places a high value on suffering, the archetype being Jesus's suffering during the crucifixion.

Forgiving and valuing suffering are not effective strategies for an oppressed group to force social change. These activities reinforce existing power disparities and encourage the disempowered to accept their real-world disadvantages as spiritual advantages.

Forgiving and valuing suffering are particularly dangerous strategies for battered women. ${ }^{60}$ Such teachings encourage battered women (who are all too likely to believe their batterers who ask forgiveness and swear they will never do it again) to stay in extremely destructive relationships. Religious counselors often advise battered women to "pray for guidance, become better women, and go home and help their husbands 'become more spiritual and find the Lord." "61

Even more perversely, the Christian valuation of suffering encourages women to accept abuse. Christian theology glorifies victimization, posing special hazards to women because society, as well as Christianity, assigns them the "suffering-servant role."62 Joanne Carlson Brown and Rebecca Parker make this point powerfully:

Christianity has been a primary-in many women's lives the primary-force in shaping our acceptance of abuse. The central image of Christ on the cross as the savior of the world communicates the message that suffering is redemptive. If the best person who ever lived gave his life for others, then, to be of value we should likewise sacrifice ourselves. Any sense that we have a right to care for our own needs is in conflict with

s9 Morgan, The Total Woman at 144 (cited in note 53) (citing King James Version of the Bible).

${ }^{8}$ See McDonald, 2 Yale $\mathrm{J} \mathrm{L}$ and Feminism 251 (cited in note 30).

6t Walker, The Battered Woman at 23 (cited in note 52).

62 Joanne Carlson Brown and Rebecca Parker, For God So Loved the World?, in Joanne Carlson Brown and Carole R. Bohm, eds, Christianity, Patriarchy, and Abuse: A Feminist Critique 1, 3 (Pilgrim, 1989). 
being a faithful follower of Jesus. Our suffering for others will save the world. ${ }^{63}$

Thus, the values at the core of the Christian tradition reinforce and contribute to women's suffering and subordination.

5. Female sexuality and mothering.

Traditionally, Judaism has linked 'women's bodies with uncleanliness, regarding menstrual blood and childbirth as polluting. Prior to menopause, the Jewish faith deems a woman unclean for two weeks of every month: while she is menstruating and for seven days thereafter until she has "undergone ritual purification in a mikveh" (ritual bath). ${ }^{64}$ After childbirth, purification of the woman's body is also necessary. ${ }^{65}$ Instead of celebrating women's reproductive power, Judaism perceives women's bodies (and women themselves) as unclean and polluted.

Judaism nevertheless sees marriage (and sexuality) as a positive experience, a necessary part of life for an observant member of the community. The blessing given the newborn child is to grow up to Torah, marriage, and good deeds. Orthodox congregations do not hire unmarried rabbis nor do they usually hire unmarried cantors.

Christianity more consistently approaches women's bodies and sexuality negatively, linking women with sexuality and sexuality with imperfection and $\sin ^{66}$ For example, Clement of Alexandria wrote that for women, "the very consciousness of their own nature must evoke feelings of shame." ${ }^{67}$ The equation of women with sex may seem odd, since men seem more interested in genital sex than women do. But, from the perspective of heterosexual men who feel sexual desire but regard sexual intercourse as "filthiness" and "disgustingness" (the terms belong to St. Thomas Aquinas ${ }^{68}$ ), there is a certain logic in regarding women as the source of the evil. Were there no women, these men would not be tempted to engage in such repulsive activities. ${ }^{69}$

${ }^{63}$ Id at 2.

* Paula Hyman, The Other Half: Women in the Jewish Tradition, in Koltun, ed, The Jewish Woman 105, 110-11 (cited in note 55).

${ }^{65}$ Heschel, ed, On Being a Jewish Feminist: A Reader 286 (cited in note 54) (glossary entry for mikvah at back of book).

${ }^{68}$ Bullough, The Subordinate Sex at 97-101 (cited in note 35).

${ }^{67}$ Uta Ranke-Heinemann, Eunuchs for the Kingdom of Heaven: Women, Sexuality, and the Catholic Church 127 (Doubleday, 1990) (quoting Paedagogus II, 33, 2.).

Bs Id at 194.

69 Bullough, The Subordinate Sex at 84 (cited in note 35). 
During much of Christian history, all sexual intercourse, even within marriage, was tainted. Augustine and Thomas Aquinas regarded original sin as transmitted via sexual intercourse (even when unaccompanied by pleasure). ${ }^{70}$ For centuries, active sexuality ranked inferior to celibacy, and often was regarded as sinful even within marriage. ${ }^{71}$ For example, Augustine regarded any married person who requested sex for pleasure, rather than procreation, as committing a venial sin..$^{72}$

The equation of women with sexuality and sexuality with impurity and sin remains strong in Roman Catholicism, with its allmale celibate clergy and its rejection of contraception (which permits sex for pleasure). Most other Christian denominations permit clergy to marry, regard the married life as consistent with holiness, and permit contraception. But traces of the equation of women with sex and sex with sin persist. For example, most Christian denominations still insist on a belief in the Virgin Birth. The Virgin Birth distances ordinary women from the Christian ideal: ordinary reproduction and mothering are tainted. If Mary is "pure" because she never had sex, all other mothers are impure because they did. Again, religious doctrine offers different things to women and men. In the areas of sexuality and reproduction, religion stresses female impurity and male creative power.

6. Christian sin and virtue.

Christianity defines as sin what is most likely to be the sin of men: putting one's own development and needs ahead of others. It defines as virtue self-sacrificing love. ${ }^{33}$ But self-sacrifice is often women's sin. Christianity thus encourages women to do what society encourages them to do as caretakers and nurturers: hide their own talents and find fulfillment vicariously through service to the talents of others. This very sacrifice tends to be the sin of women, who are too likely to dissipate themselves "in activities which are merely trivial" in the service of others. ${ }^{74} \mathrm{~A}$ woman's greatest temp-

70 Ranke-Heinemann, Eunuchs for the Kingdom of Heaven at 192-93 (cited in note 67).

71 Id at 27-28.

72 Id at 95.

${ }^{73}$ There is only one gospel parable about failing to develop one's talents. See Matthew 25:14-30 (New English Bible). In contrast, the gospels are full of verses on the need for humility. Christian churches continue to define sin primarily as pride rather than hiding.

74 Valerie Saiving, The Human Situation: A Feminine View, in Carol P. Christ and Judith Plaskow, eds, Womanspirit Rising: A Feminist Reader in Religion 25, 38 (Harper \& Row, 1979). Keller carries this insight further, noting that "God the Father" is the embodiment of Christian (male) sin. See Keller, From a Broken Web at 38-40 (cited in note 45). 
tation is to hide her talents rather than develop them, sacrificing her development as an autonomous self in order to serve others. A woman who does this is:

guilty of the sin of hiding; inasmuch as she has poured herself into vicarious living, inasmuch as she has denied her sense of self in total submission to husband/father/boss or in total selfgiving to children, job, or family, she has been guilty of the sin of hiding. As she has been afraid to dream a dream for herself as well as for others, and as she has trained herself to live a submerged existence, she has hidden from her full humanity. ${ }^{75}$

Thus, the dominant conceptions of both Christian virtue and sin discourage women from developing as autonomous beings. Focusing on men's sin as the sin and extolling women's sin as virtue is a likely result of male domination of a religious tradition. Theology, like theory, is in large part autobiography. For most men, Christianity has correctly identified sin and virtue. Following Christian teaching helps men to become better people. But men have neither the insight nor any incentive to define women's sin in a way that will encourage women to become more self-interested. Instead, men define sin in a way that encourages women to sin rather than to work against their real temptations. It is possible to have it both ways; Christianity could give equal emphasis to both women's sin (hiding) and men's sin (pride), stressing the need to avoid both. Had women participated equally as leaders in Christianity, it is likely that Christianity would do so rather than perpetuate "woman's bondage to her hiddenness." ${ }^{6}$ To reiterate my major point, religion does not mean for women what it means for men.

7. Christianity and traditional roles for women: Mary the mother.

Mainstream Christian religions present, as ideal, traditional images of women as caretakers, nurturers, servants of others. ${ }^{77}$ Mary, the most prominent woman, is the most traditional and submissive of women: "I am the Lord's servant; as you have spoken, so

See also Susan Nelson Dunfee, The Sin of Hiding: A Feminist Critique of Reinhold Niehbuhr's Account of the Sin of Pride, 65 Soundings 316 (1982).

${ }^{75}$ Dunfee, 65 Soundings at 321-22 (cited in note 74).

${ }^{76}$ Id at 322.

${ }^{77}$ See, for example, Jerome L. Himmelstein, The Social Basis of Antifeminism: Religious Networks and Culture, 25 J Scientific Study Religion 1, 8 (1986). 
be it." 78 In contrast to the portrayal of women in a singular traditional role, men are seen in many roles: God, savior, prophet, religious leader, father, etc. Again religion offers different things to men and women. It offers men a greater range of more powerful roles.

These problems in mainstream religions, particularly Christian religions, are deeply embedded in religious belief and practice. These religions cannot eliminate the sexism easily; the use of gender-neutral language will not eradicate deeper problems. A number of commentators consider America's religious traditions "to be our most deep-seated cause of patriarchy." "No Nevertheless, religion has been and is a positive influence in many women's lives. It is a source of meaning for women more than for men, despite its patriarchal nature. I next consider the positive aspects of the complex relationship between women and religion. This exploration balances my critical discussion of religion. It does not, however, detract from my main point. Religious freedom has not given women and men the same ability to develop an extra-governmental authority for meaning, values, and morality.

\section{B. Religion as a Positive Force in Women's Lives}

In this Section, I discuss two positive aspects of religion for women. First, I explore ways in which religion has empowered women. Second, I explore ways in which religion has been affected by and reflects women's beliefs and values.

1. Religion often empowers women.

Throughout history, religion has been a source of power for individual women. Like men, many women, from Joan of Arc to African American women preachers in the nineteenth century, ${ }^{80}$ have found an authority in religion to support unconventional choices. Religious activities and organizations offered women

\footnotetext{
${ }^{78}$ Luke 1:38 (New English Bible) (Mary's reply to the angel Gabriel when informed that she will have a son, though she is a virgin).

${ }^{79}$ Anne Barstow Driver, Religion, 2 Signs 434, 434 (1976) (review essay). See also, for example, John Wilson, Religion in American Society: The Effective Presence 264 (Prentice Hall, 1978) ("Religion is probably the single most important shaper of sex roles."); Himmelstein, $25 \mathrm{~J}$ Scientific Study Religion at 7-12 (cited in note 77).

${ }^{80}$ For the stories of some of the latter, see, for example, Bert James Loewenberg and Ruth Bogin, eds, Black Women in Nineteenth-Century American Life (Penn State, 1976); William L. Andrews, ed, Sisters of the Spirit: Three Black Women's Autobiographies of the Nineteenth Century (Indiana, 1986); Jean McMahon Humez, ed, Gifts of Power: The Writings of Rebecca Jackson, Black Visionary, Shaker Eldress (Massachusetts, 1981).
} 
meaningful and respectable work in public life when many women were otherwise relegated to their homes. Women in religious orders received educations and achieved independence denied to most women. Activists in the suffrage and abolition movements first organized and pushed for change through their churches. ${ }^{81}$ Some religious groups, particularly Quakers, produced exceptionally high numbers of women leaders. ${ }^{82}$ During the nineteenth century, women used movements with religious overtones and membership, such as the temperance, voluntary motherhood, and social purity movements, to try to better the condition of women in a variety of ways. ${ }^{83}$ Although many of these women used religious networks and ideals in their organizing, they were rarely religious leaders as such. Their ability to restructure religious belief and practice was therefore limited.

Religion continues to play a positive role in the lives of many women today. Most religious Christian women today, and more women than men, regard their religious commitment as a positive experience. ${ }^{84}$ In the next Section, I explore some of the reasons why Christianity, despite and even because of its sexism, appeals disproportionately to women..$^{85}$

2. Religion reflects women's traditional roles and values.

Religious values are, in many ways, more consistent with women's roles than men's. A man's duty to support his family by succeeding in the competitive world of a market economy conflicts

81 See, for example, Eleanor Flexner, Century of Struggle: The Woman's Rights Movement in the United States (Harvard, rev ed 1975); Marjorie Wall Bingham, Women and the Constitution: Student Textbook 23-24 (Communicorp, 1990); Nancy A. Hewitt, Women's Activism and Social Change: Rochester, New York, 1822-1872 43-44 (Cornell, 1984).

82 Bingham, Women and the Constitution at 22-24 (cited in note 81).

${ }^{83}$ See, for example, Linda Gordon, Woman's Body, Woman's Right: A Social History of Birth Control in America 116-20, 131-32 (Penguin, 1977); Elizabeth B. Clark, Religion and Rights Consciousness in the Antebellum Woman's Rights Movement, in Martha Albertson Fineman and Nancy Sweet Thomadsen, eds, At the Boundaries of Law: Feminism and Legal Theory 188 (Routledge, 1991); Carolyn De Swarte Gifford, Women in Social Reform Movements, in Rosemary Radford Ruether and Rosemary Skinner Keller, eds, I Women and Religion in America: The Nineteenth Century 294 (Harper \& Row, 1981); Nancy F. Cott, The Bonds of Womanhood: "Woman's Sphere" in New England, 1780-1835 149-54 (Yale, 1977).

84 Robert Wuthnow and William Lehrman, Religion: Inhibitor or Facilitator of Political Involvement Among Women?, in Louise A. Tilly and Patricia Gurin, eds, Women, Politics, and Change 300, 302 (Russell Sage Foundation, 1990). Indeed, "[w]omen are 18 points more likely than men to say that their religious commitment has been a positive experience." Id.

ss Jews are as likely to be men as women. See George Gallup, Jr., Religion in America 50 Years: 1935-1985, in The Gallup Report No 236 at 34 (1985). 
somewhat with the virtues of mainstream Christianity. Christianity calls for humility, service to others, obedience to the laws of God (rather than the market), generosity to the poor and unfortunate, and forgiving and forgetting. These virtues better match women's traditional roles as mothers, nurturers, and enablers responsible for making home a "haven" from the heartless world of the market.

I noted earlier that Christian sin is sin for men: pride and putting oneself first. For women, real sin tends to be forgetting one's own needs and living through others, the sin of "hiding," of failing to use one's talents. Ironically, Christianity extols women's sin-self-sacrifice and vicarious fulfillment-as the primary virtue. But precisely because self-sacrifice is women's real sin, the Christian notions of sin and virtue resonate with women. Christianity gives positive meaning to women's behavior as subordinates and victims.

Women's culture and rules of conduct also identify and proscribe the sin of pride. In her recent book, You Just Don't Understand $^{86}$ Deborah Tannen studied the ways groups of girls and groups of boys interact. For girls, interaction is about sharing feelings and experiences, about empathy. Girls tend to consider it socially inappropriate to put oneself forward as superior, to out-distance one's friends in any way. Unusual success is something one apologizes for or explains away. Boys tend to see interaction as essentially about establishing hierarchy, out-distancing one's friends both in games and in other activities, using words to demonstrate that because of one's success, one out-ranks another. Given these differences, Christian sin will seem odd to boys, and out of touch with reality. For girls, Christian sin resonates with their social norms, which proscribe precisely the same thing as Christian sin. In other words, Christian virtues of service and self-sacrifice resonate deeply with girls' culture and with what girls are told they should do in order to be good wives and mothers. They make less sense for boys because they are inconsistent with boys' culture and with the traditional breadwinner role in a rough-and-tumble market economy. Thus, the appeal of Christianity is precisely its danger for women. Had more Christian theologians and preachers been women, Christianity might give equal emphasis to women's sin, and resonate with women's culture no more than with men's.

${ }^{86}$ Deborah Tannen, You Just Don't Understand: Women and Men in Conversation (William Morrow, 1990). 
In Christianity, the evangelical emphasis on inner feelings and the emotional cult of Jesus also appeals greatly to women. Evangelical movements dominated Protestantism in America in the nineteenth century and profoundly changed the content of all mainstream Christian denominations, ${ }^{87}$ shifting the devotional focus of many from a macho "God the Father" incapable of empathy to a very feminine and empathetic Jesus. For many women, religion fills an important emotional void. Educated in heterosexual romance, ${ }^{88}$ but unable to find a satisfactory male lover, women find in religion the romantic emotional union they long for and cannot find in a relationship with a man.

The Christian emphasis on suffering, as exemplified by the crucifixion, valorizes traditionally feminine masochism of the sort Freud would recognize. In part, the appeal of Christianity to women arises from its ability to give meaning to the suffering and pain of their own lives; to give meaning to all suffering and subordination.

Jewish traditions are feminine in another sense, one not shared by most Christian sects: religious rituals in the home are of great importance. Women are ultimately responsible for such rituals. This emphasis sanctifies the space traditionally reserved for women and gives significance to women's caretaking activities, especially as cooks and organizers of family holidays and rituals.

In addition, both Judaism and Christianity protect and support women in important ways. Both legitimate and value women's traditional roles. Both developed economic protections for wives and mothers. For example, canon law developed the obligations of a husband, separated from wife and children, to pay alimony and child support. These obligations became the basis of secular family law's economic supports for divorced women. ${ }^{89}$ Orthodox Judaism provides a number of property protections for a divorced wife. ${ }^{90}$ In addition, the secular idea of equality-which has been important

${ }^{82}$ See Claude Welch, 1 Protestant Thought in the Nineteenth Century: 1799-1870 2230 (Yale, 1972); Cott, The Bonds of Womanhood at 128-37 (cited in note 83). For another view of Jesus as feminine, see Roberts, Religion in Sociological Perspective at 284 (cited in note 34$)$.

s8 On the importance of romance to women, see, for example, Dorothy C. Holland and Margaret A. Eisenhart, Educated in Romance: Women, Achievement and College Culture (Chicago, 1990); Keller, From a Broken Web at 15-16 (cited in note 45).

${ }^{89}$ See Mary Ann Glendon, State, Law and Family: Family Law in Transition in the United States and Western Europe 312-13 (North-Holland, 1977).

so See, for example, Daniel I. Leifer, On Writing New Ketubot, in Koltun, ed, The Jewish Woman 50 (cited in note 55). 
in giving women a basis for arguing for social change-may have its origins in Christian ideas and ideals.

Although many feminists have left patriarchal religions because of the difficulty of reconciling their beliefs about women with traditional religious beliefs and practices, ${ }^{91}$ many other women and feminists work from within to make religions less sexist and more responsive to, and reflective of, the human condition. Within Jewish and Christian congregations, feminists are working in many ways and on many levels to make religions more responsive to women's needs. For example, feminists challenge the focus on the male sin of pride in Christianity to include the female sin of "hiding,"92 which is the "underdevelopment or negation of self."93 Feminists also bring insights to evangelical Christianity (including fundamentalist evangelical groups), ${ }^{94}$ Roman Catholicism, ${ }^{96}$ Judaism, ${ }^{96}$ and the study of early Christianity ${ }^{97}$ This outpouring of feminist insights and criticisms of mainstream religions indicates the deep attachment many women feel toward religion, even when they see its sexism.

The positive aspects of the relationship between women and religion and women's deep attachment to religion do not negate my central concern: religious freedom has not meant the same thing for women and men. Indeed, this discussion has demonstrated the close link between religion's appeal to women and its danger for women. Religion values women's traditional roles, including subordination and even suffering. Religion also offers emotional fulfillment, rather than requiring women to find fulfillment through the development of their abilities. Thus, religion reinforces women's subordinate status. It does not, of course, have this effect for men, who dominate both religion and society in general. In the next Section, I explore the empirical literature on the effect of religion on

91 Wuthnow and Lehrman, Religion (cited in note 84).

${ }^{82}$ See Dunfee, 65 Soundings 316 (cited in note 74). See notes 74-76 and accompanying text.

${ }^{93}$ Saiving, The Human Situation at 37 (cited in note 74). See also Keller, From a Broken $W e b$ at 12, 39-40, 190 (cited in note 45).

9 See Judith Stacey, Brave New Families: Stories of Domestic Upheaval in Late Twentieth Century America 139-46 (Basic, 1990) (reviewing writings of evangelical feminists).

os See generally Anne E. Carr, Transforming Grace: Christian Tradition and Women's Experience (Harper \& Row, 1988); Rosemary Radford Ruether, Sexism and God-Talk: Toward a Feminist Theology (Beacon, 1983).

${ }^{98}$ See, for example, Koltun, ed, The Jewish Woman (cited in note 55).

97 See, for example, Elisabeth Schussler Fiorenza, In Memory of Her: A Feminist Theological Reconstruction of Christian Origins (Crossroad, 1983). 
political issues important to women and on women's political participation.

\section{Empirical Evidence: Religion and Women}

Religious Christians are more likely than other Americans to take positions inconsistent with women's equality. Those who attend Christian services frequently are more likely to oppose abortion, the Equal Rights Amendment, paternity leave, affirmative action quotas, government support of day care, women keeping their birth name or using the title "Ms.," and allowing girls on boys' sports teams. ${ }^{98}$ Indeed, Christian "church attendance is generally more strongly related to [these] antifeminist beliefs than are education, income, occupational status, class, age, residence, and most other social traits." 99 Findings like these have been replicated in study after study. ${ }^{100}$

The evidence on the relationship between Jewish religious commitment and attitudes toward women is ambiguous. Female supporters of feminism are likely to have had parents who were Jewish, atheist, or agnostic and are more likely to be Jewish, athe-

s8 Himmelstein, $25 \mathrm{~J}$ Scientific Study Religion 1, 9-10 (cited in note 77). In another study, Christian church attendance was found to be correlated with traditional answers to two questions about the desirability of a traditional division of labor and power with women taking the domestic, subordinate role, and with two traditional answers about the consequences for children of maternal employment. Karen Oppenheim Mason and Yu-Hsia Lu, Attitudes Toward Women's Familial Roles: Changes in the United States, 1977-1985, 2 Gender \& Soc 39, 43, 49-51 (1988).

99 Himmelstein, 25 J Scientific Study Religion at 13 (cited in note 77).

100 See id (looking at data amassed in a number of studies, including data from general population surveys, and concluding that antifeminist attitudes are rooted in Christian religious networks); Merlin B. Brinkerhoff and Marlene M. MacKie, Religious Denominations' Impact Upon Gender Attitudes: Some Methodological Implications, 25 Rev Religious Research 365, 365 (1984) ("denomination, the typology, and attendance [at Christian religious services] tend to be more strongly correlated to gender attitudes than age or education"); Ross K. Baker, Laurily K. Epstein and Rodney D. Forth, Matters of Life and Death: Social, Political, and Religious Correlates of Attitudes on Abortion, 9 Amer Pol Q 89 (1981) (approval of abortion found to be "a function of intensity of religious adherence"); Mary Y. Morgan, The Impact of Religion on Gender-Role Attitudes, 11 Psych Women Q 301 (1987) (religious devoutness most important variable for predicting five measured dimensions of gender-role attitudes); Carol Mueller and Thomas Dimieri, The Structure of Belief Systems Among Contending ERA Activists, 60 Soc Forces 657, 664-65 (1982) (activist opponents of state ERA in Massachusetts in 1975 were all members of a church or parish; most proponents were not); Kent L. Tedin, Religious Preference and Pro/Anti Activism on the Equal Rights Amendment Issue, 21 Pac Sociol Rev 55, 64 (1978) (study of activists involved in state deliberations on national ERA in Texas in spring of 1975; anti-ERA activists tended to belong to conservative denominations). 
ist, agnostic, or Unitarian themselves. ${ }^{101}$ But these studies confound secular Jewish people who identify with their ethnic heritage and those who are religious. It is not clear whether religious Jews are less sexist than religious Christians. ${ }^{102}$ Given the content of Orthodox belief and practice, ${ }^{103}$ it is possible that at least some religious Jews possess more sexist views than secular Jews.

To be sure, there is some variation among Christian denominations with respect to issues important for women's equality. ${ }^{104}$ For example, researchers using 1980 data found that 85.7 percent of Jews, 64.3 percent of Catholics, 59.8 percent of Fundamentalist Protestants, 59.2 percent of other Protestants, and twenty-five percent of Mormons supported the Equal Rights Amendment. ${ }^{105}$ One study of students at Utah State University demonstrated that Mormon students have much less favorable attitudes toward nontraditional roles for women than do other students. ${ }^{106}$ Across Christian denominations, however, researchers have "clearly, con-

101 J.A. Dempewolff, Some Correlates of Feminism, 34 Psych Rep 671, 671 (1974). I have not found studies examining various strands of Judaism to see if they differ on this point. Even religious Jews may be relatively egalitarian as a result of stress on the Israeli norm of sexual equality (which exists at least on the level of American rhetoric). See Andrea Dworkin, Israel: Whose Country Is It Anyway?, Ms. 69, 73 (Sep/Oct 1990).

${ }_{102}$ Of those who identified themselves as Jewish in a 1975 study, only $38 \%$ were members of a synagogue and only $32 \%$ attended services. Steven M. Cohen, American Modernity \& Jewish Identity 56 (Tavistock, 1983). In 1989, Christians were 21-26\% more likely to attend service than Jews. See Tom W. Smith, Counting Flocks and Lost Sheep: Trends in Religious Preference Since World War II, in GSS Social Change Rep No 26, 53, 55 (National Opinion Research Center University of Chicago, 1991).

${ }^{203}$ See notes 58, 64-65 and accompanying text.

104 See Himmelstein, $25 \mathrm{~J}$ Scientific Study Religion at 7 (cited in note 77) ("Jews and the unaffiliated are distinctly more liberal on both ERA and abortion than either Protestants or Catholics. Protestants tend to be slightly more supportive of abortion and less supportive of ERA than Catholics. Fundamentalist and conservative Protestants are more likely to oppose both than are liberal protestants."). Himmelstein reviewed a number of population studies. See also Brinkerhoff and MacKie, 25 Rev Religious Research at 374 (cited in note 100) (some variation in gender attitudes found by Christian denomination: Mormons and Pentecostals most traditional in terms of attitudes though in terms of division of household labor and family power, Mormons among most egalitarian); Val Burris, Who Opposed the ERA? An Analysis of the Social Bases of Antifeminism, 64 Soc Sci Q 305, 308-10 (1983); Baker, Epstein, and Forth, 9 Amer Pol Q at 99 (cited in note 100) (denominational variation only modest on approval of abortion; key factor found to be intensity of religious adherence).

105 Burris, 64 Soc Sci $Q$ at 309 (cited in note 104). See also Glenna Spitze and Joan Huber, Effects of Anticipated Consequences on ERA Opinion, 63 Soc Sci Q 323, 326 (1982) (national sample: Catholics, Jews, and those without a religious affiliation more favorable to ERA than Protestants).

106 Moshe Hartman and Harriet Hartman, Sex-role Attitudes of Mormons vs. NonMormons in Utah, $45 \mathrm{~J}$ Marriage \& Family 897, 899 (1983). 
sistently"107 found a strong correlation between church attendance and opposition to the ERA ${ }^{108}$ and abortion:"109 "Religious involvement has a conservative effect [on ERA and abortion attitudes] no matter what the denomination or its doctrines (though the magnitude of the effect varies)." 110 Religious devoutness has greater predictive power with respect to five dimensions of gender-role attitudes among women undergraduates than self esteem, assertiveness, mother's education, or mother's employment. The greater the woman's devoutness, the more traditional her notions about sex roles. ${ }^{111}$

${ }^{107}$ Himmelstein, $25 \mathrm{~J}$ Scientific Study Religion at 7 (cited in note 77).

${ }^{108}$ See, for example, Burris, 64 Soc Sci Q at 309-10 (cited in note 104); Baker, Epstein, and Forth, 9 Amer Pol Q at 99-101 (cited in note 100) (survey of New Jersey voters: opposition to ERA correlates with strength of religious attachment, regardless of whether respondent Catholic or Protestant); Louis Bolce, Gerald De Maio, and Douglas Muzzio, ERA and the Abortion Controversy: A Case of Dissonance Reduction, 67 Soc Sci Q 299, 306, 310 (1986) (Center for Political Studies National Election Study Data: traditionalist early supporters of ERA reversed positions as they experienced cognitive dissonance; white religious people especially likely to switch from pro-ERA to anti-ERA); David W. Brady and Kent L. Tedin, Ladies in Pink: Religion \& Political Ideology in the Anti-ERA Movement, 56 Soc Sci Q 564, 575 (1976) (study of anti-ERA activists in Texas: 98\% church members; $66 \%$ Fundamentalist Protestant; 25\% other Protestant; 92\% religion very important).

There are feminist reasons why one might oppose the ERA. See generally Becker, 1987 $\mathrm{S}$ Ct Rev at 214-24, $215 \mathrm{n} 49$ (cited in note 16). The empirical research consistently finds a correlation between religious commitment and, not just opposition to the ERA, but more generally opposition to change in women's roles and status. See notes 98-116 and accompanying text. In fact, the states that refused to ratify the ERA were states in which women were generally worse off than the states in which the ERA was ratified. See David C. Nice, State Opposition to the Equal Rights Amendment: Protectionism, Subordination, or Privatization, 67 Soc Sci Q 315, 324-25 (1986) (states supporting ERA had lower divorce rates; better AFDC benefit levels; better control of domestic violence; were less likely to have women on death row; were less likely to have called for banning abortion; were less likely to have required school segregation). This suggests that opposition was not grounded on a commitment to women's welfare, but an opposition to increased status for women. Id at $326-27$.

${ }^{109}$ See, for example, Baker, Epstein, and Forth, 9 Amer Pol Q at 99-100 (cited in note 100) (survey of New Jersey voters: opposition to abortion correlates with strength of religious attachment, rather than with being a Catholic or Protestant); Sharon Marmon and Howard A. Palley, The Decade After Roe Versus Wade: Ideology, Political Cleavage, and the Policy Process, in Gwen Moore and Glenna Spitze, eds, 2 Research in Politics and Society: Women and Politics: Activism, Attitudes, and Office-Holding 181, 194 (1986) ("Among Catholics and Protestants who are frequent and regular churchgoers, church attendance strongly correlates with opposition to abortion on demand, a correlation which is considerably stronger with respect to Catholics than to Protestants.").

${ }^{110}$ Himmelstein, $25 \mathrm{~J}$ Scientific Study Religion at 8 (cited in note 77). This author notes that "differences are more marked for Catholicism than for Protestants and for the more conservative protestants than the less conservative ones, but they are present across the board." Id at 7.

111 Morgan, 11 Psych Women $Q$ at 305-06 (cited in note 100). Morgan measured five gender-role attitudes: 
Interestingly, the correlation between Christian religious commitment and sexist attitudes contrasts with the relationship between such commitment and racist attitudes. Although moderately active Christians are, on the average, more racist than those who do not attend church, the most committed church members are as tolerant of racial minorities as non-members. ${ }^{112} \mathrm{By}$ contrast, church members are more sexist than the nonaffiliated, and the most committed churchmembers are the most sexist. ${ }^{113}$

The reader may object that religious activities (or perhaps Christian religious activities) do not "cause" antifeminist or other political attitudes or acceptance of traditional women's roles. Rather, those with traditional attitudes are more likely to be members of religious groups, especially conservative religious groups. Thus, self selection explains the correlation between religious involvement and antifeminist beliefs.

But children are not born with either sex-role attitudes or religious commitments. Rather, they are socialized within religious communities and by parents with certain beliefs. There is a high correlation between one's religious training as a child and one's religious commitment as an adult. For example, ninety-one percent of those "raised as Baptists say they are Baptists today."114 For Episcopalians, the figure is ninety percent; for Lutherans, eightynine percent; for Methodists, seventy-four percent; for Presbyterians, seventy-two percent; for Catholics, eighty-one percent; for Jews, eighty-six percent; for those with no religion, forty-four percent. ${ }^{115}$ The fact that parents so successfully socialize their chil-

(a) familial roles, i.e., mothers' and fathers' roles pertaining to household division of labor and care of children; (b) extrafamilial roles, i.e., roles of men and women regarding career commitment, decisionmaking, and leadership ability; (c) male/female stereotypes, i.e., beliefs about the innate characteristics of men and women such as male superiority and female dependency; (d) social change as related to sex roles, i.e., changes in social structure necessary for equality in male/female roles such as equal pay and equal job opportunities ...; and [(e)] gender-role preferences for role of wife, i.e., the role of a woman in relationship to her husband when she is working outside the home.

Id at 302 (citations omitted).

112 Richard L. Gorsuch and Daniel Aleshire, Christian Faith and Ethnic Prejudice: A Review and Interpretation of Research, 13 J Scientific Study Religion 281, 285 (1974). "The more intrinsically religious, nonfundamentalistic, and theologically discriminating persons were also more tolerant." Id at 281. See also Keith A. Roberts, Religion in Sociological Perspective 261-79 (Wadsworth, 2d ed 1990).

${ }_{113}$ Roberts, Religion in Sociological Perspective at 280-300 (cited in note 112).

14 Public Opinion Report: America: Land of the Faithful 96, 101 n (American Enterprise, 1990).

${ }^{115}$ Id (again, the figure for Jews would include both religious and secular Jews). I am not asserting that adults never choose religion. Fifty-six percent of those raised without 
dren into their religion means that we cannot regard correlations between sexist attitudes and religious beliefs as the result of selfselection by autonomous adults. To the extent religious beliefs correlate with antifeminist beliefs, sexual equality for younger generations conflicts with religious freedom for older generations. ${ }^{116}$

Further, to the extent "autonomous" adults do chose religion, the correlation between church devotion and antifeminist political views should be troubling because of the unavailability of any nonsexist religious tradition in the American mainstream. Adults have only a limited set of options-a set that does not include any tradition in which women have been leaders in appropriate levels for any period of time (let alone the millenia over which mainstream religious traditions have developed). If a nonsexist religion were part of the American mainstream, we would live in a culture rather different from the present one, and "autonomous" adults in that culture would likely make quite different choices from those made by "autonomous" adults in this culture. That people choose from the options available to them cannot justify the range of options.

The studies already cited suggest that mainstream Christian religions contribute to women's subordinate status in society at large: churchgoers are more likely to take antifeminist positions on political issues important to women. ${ }^{117}$ Mainstream Christian religions also impede women's success as politicians. Researchers have found a negative correlation between fundamentalist membership within a state and female representation in the state legislature. ${ }^{118}$ A study of female candidates running for state and national office from New York city and two neighboring counties found Catholic women underrepresented and Jewish women overrepresented. ${ }^{119}$

Churches also engage directly in politics. Protestant and Catholic organizations are often used to rally opposition to feminist is-

religion nevertheless have a religious affiliation as adults. My point is that particular religious beliefs are passed on from one generation to the next; one cannot, therefore, assert that religious beliefs are the result of choice by "autonomous" adults. If all children were raised without religion, fewer would be associated with religious organizations as adults (and more would be feminists as adults).

116 Wisconsin v Yoder, 406 US 205, 241-46 (1972) (Douglas dissenting in part) (pointing out that religious freedom of high school-age Amish children may conflict with their parents' religious freedom).

11 See text accompanying notes 98-111.

118 See, for example, Thomas J. Bolgy, John E. Schwarz, and Hildy Gottlieb, Female Representation and the Quest for Resources: Feminist Activism and Electoral Success, 67 Soc Sci Q 156, 161 (1986).

${ }^{11}$ Nikki R. Van Hightower, The Recruitment of Women for Public Office, 5 Amer Pol Q 301, 311 (1977). 
sues, and thereby have a very direct impact on politics. ${ }^{120}$ Catholic prelates have been more willing to criticize female Catholic politicians (as compared to men) for failing to follow official doctrine. ${ }^{121}$ Yet many Protestant and Catholic organizations enjoy significant tax and postage advantages over women's political organizations such as NOW PAC.

The empirical work on religion and women examined in this Section shows that religion is a political problem for women. Christian religious values support the sexual status quo. Christians disproportionately favor antifeminist positions. In part, this is because sexism pervades religious doctrines and practices in content and effect. In part it is because religious organizations are political actors and are led by men. In the next subsection, I examine the extent to which government subsidizes religion despite its antidemocratic effects.

\section{Government Support for Religion}

In the United States, we have neither separation of church and state nor state neutrality toward religion. Rather, the government contributes significantly to religions. I briefly give three examples: 1) Lynch v Donnelly ${ }^{122}$ ("the creche case"); 2) tax and postage advantages; and 3) income tax-free housing subsidies for "ministers of the gospel." In each of these examples, the governmental subsidy is troubling for two reasons. The first is a general objection: subsidies to mainstream religions contribute to women's subordinate status generally and within the political system. The second is an objection to more specific practices. In the creche case, the government subsidized a sexist image. In the case of tax and postal subsidies, religions, which mobilize opposition to feminist issues, receive benefits denied women's political organizations. And housing subsidies reinforce and magnify discriminatory employment practices within religious organizations.

The reader may object that the Bill of Rights does not cause the problems in these three areas: it does not mandate the display of sexist imagery on government property, require tax exemptions from generally applicable taxes, or require housing subsidies. In-

${ }^{120}$ See, for example, Kenneth D. Wald, Dennis E. Owen, and Samuel S. Hill, Jr., Churches as Political Communities, 82 Amer Pol Sci Rev 531, 533-34 (1988); Himmelstein, $25 \mathrm{~J}$ Scientific Study Religion at 8 (cited in note 77).

121 See, for example, Geraldine A. Ferraro with Linda Bird Francke, Ferraro: My Story 222 (Bantam, 1985).

122465 US 668 (1984). 
deed, the housing subsidy may be unconstitutional under the Establishment Clause. ${ }^{123}$ My point is that, except for the housing subsidy, the Bill of Rights does not prohibit these subsidies. When they are held unconstitutional, as in the housing subsidy case, it is not because they discriminate against women. Indeed, the conflict between religious freedom and equality for women is not even visible in the literature or caselaw of the First Amendment.

\section{Lynch.v Donnelly.}

In Lynch $v$ Donnelly the Supreme Court held that the Establishment Clause does not prohibit a merchants' association in Pawtucket, Rhode Island, from erecting a creche (along with a number of other symbols, including a clown, an elephant, and a teddy bear) in a public park. ${ }^{124}$ This governmental subsidy for religion-allowing public property to be used for the display of religious symbols-is not neutral with respect to sex for two reasons. First, most religion is patriarchal and governmental subsidies of religion will, therefore, reinforce patriarchal traditions. Second, an image of the Holy Family displayed on government property raises a more particular set of problems.

The relationship between Mary and Jesus embodies a male fantasy of the ideal mother-son relationship. Jesus is more important; he is the son of God. Mary, as a mere mortal, exists to serve him. Jesus will grow to be a powerful and active male with an important mission. Mary plays only a passive supporting role. The birth of Jesus had nothing to do with his mother's sexual pleasure or even sexuality. The reproductive agency of "God the Father" overshadows the reality of female reproductive power. ${ }^{125}$ Admittedly, the virgin Mary is a positive female image-it might be worse to have no women at all. Moreover, both men and women are supposed to emulate the ideal of submission to the will of God. But, as noted earlier, the message of submission to God's will addresses men's sin (pride) more than women's sin (passivity) and Mary's virginity is a denial of female sexuality and reproductive power. ${ }^{126}$ This message is a barrier to women's equality and effec-

${ }^{123}$ See note 134 and accompanying text.

124465 US at 685 . The Court has subsequently held that a creche not surrounded by animals or other secular symbols cannot be constitutionally placed on government property. County of Allegheny $v$ ACLU, 492 US 573, 621 (1989).

125 See, for example, Daly, Gyn/Ecology at 83 (cited in note 39).

${ }^{126}$ See text accompanying notes 73-74, especially Saiving, The Human Situation (cited in note 74 ). 
tive political participation because it reinforces men's superior status and political dominance. ${ }^{127}$

Of course, the sexism in the imagery of the creche is likely to have only trivial consequences, compared with much more harmful sexist imagery, such as pornography and advertising aimed at selling clothes or beauty products to women by making women feel inadequate. For this reason, I would not recommend excluding such religious symbols from government property because of the harm they cause to women. But the sexism in such symbols should not remain invisible in legal analysis. And perhaps such sexism should justify compensatory "affirmative" action.

2. Tax and postage breaks for religious organizations.

Although religious organizations and feminist political organizations both act politically on issues important to women, such as abortion, they do not receive equal treatment in terms of either taxes or postage rates. The Constitution permits the government to subsidize antifeminist religious organizations yet deny equal treatment to feminist political organizations.

To illustrate this point, I compare the treatment of the Catholic Church, a politically active religious organization, and the treatment of a feminist political action organization, NOW PAC. The government treats these two organizations similarly in terms of income tax on organizational income: both are exempt, since NOW $\mathrm{PAC}$ is a nonprofit organization. ${ }^{128}$ But all states exempt the Catholic Church from paying property taxes for churches. ${ }^{129}$ Many states exempt all church-owned property used exclusively for religious purposes. ${ }^{130}$ Most states exempt the Catholic Church from

127 See Section I.B.2.

12826 USC \& 527(a).

129 Richard R. Hammar, Pastor, Church \& Law 378 (Gospel Publishing, 1983). In order to qualify for federal income tax exemptions, a religious corporation must not intervene or participate directly in political campaigns at all (i.e., it cannot support or oppose specific candidates). Id at 340-41. Nor is the organization allowed to undertake "substantial efforts to influence legislation." Id at 336-40. There is no bright line for determining when such efforts are substantial. Id. The Catholic Church has never lost its tax exempt status despite the fact that it teaches a position on abortion inconsistent with legislation allowing women to choose and despite the use of church networks and events to rally opposition to abortion rights. Nor did the Catholic Church lose its status when prelates attacked Geraldine Ferraro because of her position on abortion. See Ferraro, My Story at 211-39 (cited in note 121).

${ }^{130}$ Hammar, Pastor, Church \& Law at 378 (cited in note 129). Others exempt parsonages in addition to churches. Id. 
sales taxes, use taxes, and personal property taxes as well. ${ }^{131}$ NOW PAC must pay these taxes. Contributors to the Catholic Church can deduct their contributions from income in calculating income tax. ${ }^{132}$ Contributors to NOW PAC cannot. The Catholic Church can take advantage of subsidized mail rates which are unavailable to NOW PAC. ${ }^{133}$

Subsidies to mostly patriarchal religions are not gender neutral in two obvious respects. First, they are equivalent to taxpayer funding of sexist institutions. Second, these subsidies have political effects that are detrimental to women.

3. Income tax treatment of housing for "ministers of gospel."

The Internal Revenue Code permits a "minister of the gospel" to exclude housing costs or a housing allowance from income for tax purposes. ${ }^{134}$ As interpreted by the courts and the IRS, this exemption is available only to ordained ministers and those holding equivalent positions in congregations without ordained clergy. ${ }^{135}$

Like other governmental subsidies of religion, this policy is troubling on two levels. First, it subsidizes only institutions that are mostly patriarchal because it subsidizes only religious workers and not other people. Second, because of the specifics of the provision, it magnifies traditional discrimination by religious groups with respect to leadership positions, giving the benefit only to those religious workers who are likely to be male: people who are either ordained ministers or the functional equivalent. ${ }^{136}$ Women's traditional roles in congregations-as teachers, support staff, etc.-do not qualify under this provision, even when the women are full-time employees. ${ }^{\mathbf{1 3 7}}$ Although this provision of the federal

131 See Texas Monthly, Inc. v Bullock, 489 US 1, 29, 30 n 2, 32 n 3 (1989) (Scalia dissenting) (lists many state exemptions from sales and use taxes). The majority struck down a Texas exemption from sales and use taxes that applied only to religious periodicals and not to "similar" charitable or educational organizations. Id at 25.

13226 USC $\S 170(\mathrm{~b})(1)(\mathrm{A})(\mathrm{ii})$.

133 See 39 USC § 3626 (1991). Second and third class rates are available at a discount to religious, educational, scientific, philanthropic, agricultural, labor, veterans, and fraternal organizations if they are nonprofit and meet other requirements. 39 USC $\$ 3626$ (a)(1) (1991) (incorporating former code sections 39 USC $\$ \$ 4358,4359,4421,4422,4452$, and 4554). Qualified political committees may also mail at the discounted third class rates, but must be part of a political party. See 39 USC $\S \S 3626(e)(1)$ and $3626(2)(A)$. NOW PAC would not qualify, nor would any other women's organization since no women's political party exists.

13426 USC § 107.

${ }^{135}$ See IRS Rev Rule 78-301 (Jewish cantor qualified as "minister of the gospel").

${ }^{136}$ Treas Reg $\$ 1.107-1(a)$.

137 IRS Private Letter Ruling 8614010 (unordained teachers did not qualify). 
tax code is probably vulnerable to constitutional challenge in light of a 1989 Supreme Court case holding that a tax exemption applicable only to religious activities is unconstitutional, ${ }^{138}$ it remains in effect. And if the Court does overrule it, I doubt that discrimination against women religious workers will inform the decision.

There are no estimates of the total taxpayer subsidies for religious organizations through postage and tax breaks including the housing exemption, but the amount is quite large. One recent case involved over $\$ 100,000$ in sales taxes imposed on the Jimmy Swaggart Ministries' sales of religious materials through the mail over a period of about eight years in a single state. ${ }^{139}$ In fiscal year 1985, Congress appropriated $\$ 723.6$ million to subsidize postage for qualifying organizations; about forty-five percent of the qualifying organizations were religious. ${ }^{140}$ Total annual government subsidies to religious organizations in the United States as a result of exemptions and direct subsidies must be well in the billions.

I have discussed three ways in which government supports mostly patriarchal religions: through the display of religious symbols on government property; through tax and postage breaks for religious organizations; and through exemptions from income tax for housing allowances for ministers of the gospel. This is not, of course, an exhaustive list. Myriad federal and state laws and policies support religion. I mention two others briefly as illustrations of the breadth of the problem, though many more exist. First, governments routinely hire religious organizations to perform governmental services, such as caring for abused or neglected families and children, sometimes in religious institutions. ${ }^{141}$ Second, the Supreme Court has permitted federal funding of religious counseling programs on teenage sexuality, ${ }_{1}^{142}$ though such programs reflect religious organizations' sexist attitudes toward sexuality, especially those of the Catholic Church.

138 Texas Monthly, 489 US at 25.

139 See Brief for Appellant 8-9, The Jimmy Swaggart Ministries v Board of Equalization of California S Ct No 88-1374, 493 US 378 (1990).

${ }^{140}$ See Richard Kielbowicz and Linda Lawson, Reduced-Rate Postage for Nonprofit Organizations: A Policy History, Critique, and Proposal, 11 Harv J L \& Pub Pol 347, 39899 (1988).

${ }^{11}$ See, for example, Catholic Agency to Operate Youth Shelter, Chi Trib 3 (May 13, 1988) (describing temporary shelter and more permanent institution for abused or delinquent children to be run by Catholic Charities); State Seeks to Overhaul its Shelters, Chi Trib 5 (Jul 28, 1989) (describing a child intake center for young neglected or abused children run by Catholic Charities: Columbus-Maryville Reception Center).

${ }^{1 * 2}$ Bowen v Kendrick, 487 US 589, 621 (1988). 
True, government receives services in exchange under these kinds of programs, but hiring sexist religious organizations to perform governmental functions is not sex-neutral. Such contracts support religion and increase its power. Indeed, such programs often give governmental power as well as money to religion.

In this Section, I have discussed both the positive and negative aspects of mainstream religion for women and the relevant empirical evidence. As I stressed in the Introduction, my major point is purely critical: the religion clauses of the First Amendment do not have the same meaning for women and men. These clauses have not empowered women as much as men to develop an autonomous source of authority, meaning, value, and morality independent of the state. Instead, these clauses shield from state regulation deeply patriarchal institutions which impede women's political effectiveness in a democracy. Indeed, the Religion Clauses, at least as currently interpreted, allow the government to magnify the subordinating effects of religion by subsidizing it and giving governmental power to religious activities. There has been too little appreciation of this point in the legal literature. I know of no other discussion of this point, though there is some appreciation of the conflict between religious freedom for parents and children's interests in education or health care. ${ }^{143}$

We cannot expect the Bill of Rights to establish all the social rights women need. I do, however, suggest a change that we could implement by interpretation or amendment. In interpreting the First and Fourteenth Amendments, the Court could hold unconstititutional tax subsidies, tax exemptions, or the award of government contracts to religions that discriminate overtly and admittedly on the basis of sex in hiring leaders.

On this view, the Constitution compels a Bob Jones approach to religions that discriminate on the basis of sex in leadership positions. In Bob Jones, the IRS denied charity status to a religious university that discriminated on the basis of race. ${ }^{144}$ The religious university prohibited interracial dating because the religion disapproved of interracial marriage. The Supreme Court held that the denial of charity status to such an institution was statutorily permissible. The case is understood to indicate that the Supreme

${ }^{143}$ See, for example, Wisconsin v Yoder, 406 US 205, 242-46 (1972) (Douglas dissenting) (pointing out that religious freedom of high school-age children may conflict with their parents' religious freedom); In re Eric B. v Ted B., 189 Cal App 3d 996, 1008-09 (1987) (blood transfusion ordered for child whose parents' religion would not permit it).

${ }^{144}$ Bob Jones University v United States, 461 US 574, 604-05 (1983). 
Court does not regard the IRS interpretation of the statute as unconstitutional. If the Court had regarded the IRS interpretation as unconstitutional, it would have interpreted the statute to avoid the constitutional problem. Thus, a denial of a benefit to a religious organization that admittedly and overtly discriminates on the basis of race does not violate either of the Religion Clauses.

The Constitution may compel this approach in the context of race. The grant of a tax advantage to a racist university is state action. And in both Shelly v Kraemer, ${ }^{145}$ involving government enforcement of a racially exclusionary covenant, and Burton $v$ Wilmington Parking Authority, ${ }^{146}$ involving the government's grant of a lease to a racially discriminatory restaurant, the Supreme Court held that similar private racial discrimination was impermissible when accompanied by similar state action. ${ }^{147}$

This approach could and should extend to banning tax exemptions and postal subsidies and the award of government contracts to religious organizations that close leadership positions to women. Like anti-miscegenation policies (Bob Jones), and segregation in housing (Shelley) and in places of public accomodation such as restaurants (Burton), keeping women out of leadership positions denies women the opportunity to participate in society as equals. Keeping women out of religious leadership positions precludes a necessary prerequisite for religious freedom to mean as much to women as to men. For example, the sexist imagery of the creche, whether on government property or elsewhere, is less likely to change if women are not religious leaders. At the same time, denying benefits to religions that overtly close leadership positions to women would not involve greater governmental entanglement with religion than denying benefits to religious universities with antimiscegenation policies. Under this interpretation, the Constitution would prohibit benefits only to religions or religious institutions which overtly and admittedly deny women religious autonomy and free exercise.

Thus, the Court could regard a Bob Jones approach as constitutionally compelled when religions close leadership positions to women. Grants of tax exemptions or subsidies or government contracts to such organizations are state action and the state cannot discriminate on the basis of sex without an exceedingly strong justification. Religious liberty cannot justify the exemption, since

\footnotetext{
${ }^{165} 334$ US 1 (1948).

148365 US 715 (1961).

147 Shelley, 334 US at 23; Burton, 365 US at 726.
} 
these organizations deny women the religious liberty they offer men. To be sure, denial of such subsidies will "hurt" religions that close leadership to women just as the denial of tax exempt status hurt Bob Jones University. ${ }^{148}$ Our unwillingness to take action with respect to this blatant sex discrimination reflects our priorities. At present, religious freedom for some men and women justifies affirmative support for institutions subordinating women and denying women full religious freedom. At the very least, we should rethink our decision to foster such institutions.

We could modify the Constitution to proscribe religious subsidies altogether, or even to require state regulation of religion to eliminate sexism. I would not, however, favor these approaches. I think that all people need sources of authority outside government. Too much government control would preclude the ability of religion to perform that function. My only suggested change in this area is, therefore, exceedingly moderate.

\section{Free Speech and Press}

Amendment I to the Constitution guarantees "freedom of speech" and freedom "of the press." 149 In a society with a mass culture, where institutions of the "press" wield immense power, the freedom of the press assumes particular importance. The First Amendment views the "press" (television, movies, videos, books, video games) as largely beyond the reach of government regulation. Yet the "press," particularly its most powerful organ, television, impedes the democratic functioning of our political system. I discuss this problem in terms of both race and sex..$^{150}$ In addition, a "free" market in speech means that the market, governed by ability to pay, determines who can speak.

Although white men are a minority in this country, television presents a world in which white men are the majority of the popu-

148 For an argument that distinguishing between religions that overtly discriminate and those that do not is a violation of the Establishment Clause (and Bob Jones was therefore wrongly decided), see Miles, 8 Harv Women's L J 31 (cited in note 30) (arguing that all subsidies to religions should therefore end).

149 US Const, Amend I.

${ }^{150}$ In each case, there can be no absolutely firm evidence of causation. For example, correlations are always ambiguous since television viewing may not cause the observed trait but rather be related to other factors that cause both the observed trait and television viewing. I assume, for this discussion, that television does influence viewers' attitudes, especially the attitudes of young viewers. 
lation as well as socially dominant. ${ }^{151}$ As one group of researchers expressed it, "[t]he prominent and stable overrepresentation of well-to-do white males in the prime of life dominates prime time."152 In 1989, only twenty-nine percent of the leads in feature films were for actresses. And a number of those parts were prostitutes, though prostitutes are a very small part of the population of women. ${ }^{153}$ Minorities and women rarely appear as authorities on television. ${ }^{154}$ When women do appear as authorities, they frequently espouse positions regarded as anti-women. ${ }^{155}$ Television and films about caretaking portray men more often than women in the lead caretaking roles, contributing to the invisibility and undervalvation of women as caregivers. ${ }^{156}$

Media sports pervade American culture, and almost all sports heroes are male. Women's team sports do not receive national television coverage. When women do appear in popular sports events, such as Olympic gymnastics or ice skating, aesthetics-watching the female body in motion in a revealing costume-dominate. Even women tennis stars (the most visible non-Olympic women athletes in the national media) are held to an aesthetic standard more demanding, especially with respect to weight, than that applied to men. ${ }^{157}$

The visual media (film, television, magazines) inevitably stress appearance. But for women, the standard of beauty is both more demanding and of more singular importance than for men. In part, this is because women are more often defined as sex objects. Even when not presented solely as sex objects (for example, when portrayed as a business person with a briefcase in a credit card advertisement), women are almost always young and beautiful. The

151 See, for example, Matilda Butler and William Paisley, Women and the Mass Media: Sourcebook for Research and Action 78 (Human Sciences, 1980) (reporting that in the thirteen studies of the relative appearance of women and men over a twenty year period, the appearance of women became less frequent; overall, men were $72 \%$ of all characters and women $28 \%$; one study found that $79 \%$ of all white characters were men and $90 \%$ of all black characters were men).

182 George Gerbner, et al, Charting the Mainstream: Television's Contributions to Political Orientations, $32 \mathrm{~J}$ Commun 100, 106 (1982).

${ }^{163}$ Gene Siskel, It's the Streep Mystique, Chi Trib Arts 4 (Sep 2, 1990).

134 For example, most voice overs in commercials are male voices. See Butler and Paisley, Women and the Mass Media at 69-70 (cited in note 148).

${ }_{15 s}$ See Sunstein, $59 \mathrm{U}$ Chi L Rev at 284 (cited in note 2).

${ }^{168}$ See Judith Posner, Where's Mom? With more men in the kitchen, TV mothers fade from the screen, 49 Media \& Values 6 (1989). On the undervaluation of women's caretaking in the context of child custody standards, see Mary E. Becker, Maternal Feelings: Myth, Taboo, and Child Custody, 1 S Cal Rev L \& Women's Stud (forthcoming 1992).

${ }^{167}$ See John Feinstein, Hard Courts 201-02 (Villard, 1991). 
ubiquitous message confirms reality: a woman's body determines her value, even as a business professional. ${ }^{158}$ Advertising is particularly damaging to women; it sells products to women by making women feel inadequate. ${ }^{158}$

Pornography-sexually explicit material presenting women's subordination as sexy-exemplifies the politics of sexuality in the media. Andrea Dworkin states: "The major theme of pornography as a genre is male power, its nature, its magnitude, its use, its meaning. . . . Male power is the raison d'etre of pornography; the degradation of the female is the means of achieving this power."160 And pornographic themes-that women are sex objects available for male pleasure at all times-pervade mainstream media such as MTV and visual advertising. ${ }^{161}$

Children's television programs are actually more sexist than programs for adults. A 1982 study found that women and minorities appeared even less in children's television than in prime time. When present, women were "portrayed in a more stereotyped manner in children's programming than in prime-time programming." 162 Children's television has not improved since 1982. As of late April, 1991, no Saturday morning children's show featured a girl heroine. ${ }^{163}$ The networks had cancelled the only Saturday morning cartoon show with a female lead because only girls were watching the show. ${ }^{164}$ Girls will watch shows with boys in leading roles, but boys will not watch shows with female leads. ${ }^{165}$ Many shows, like Garfield, are essentially all male; others may have one female, under the "Smurfette principle." The Smurfette principle presents "a group of male buddies . . . accented by a lone female, stereotypically defined." ${ }^{166}$ The message: "boys are the norm, girls the variation; boys are central, girls peripheral; boys are individuals, girls types." ${ }^{167}$ Children's television also emphasizes the impor-

${ }^{158}$ See generally, Naomi Wolf, The Beauty Myth: How Images of Beauty Are Used Against Women (Morrow, 1991); Robin Tolmach Lakoff and Raquel L. Schèrr, Face Value: The Politics of Beauty (Routledge \& Kegan Paul, 1984).

169 Wolf, The Beauty Myth at 276-77 (cited in note 158).

${ }_{160}$ Andrea Dworkin, Pornography: Men Possessing Women 24-25 (Dutton, 1989).

161 See, for example, Fred Pelka, "Dreamworlds": How the Media Abuses Women, 21 On The Issues 20 (1991).

${ }^{162}$ John Corry, Children's TV Found Dominated by White Men, NY Times C14 (Jul 15, 1982).

${ }^{163}$ Lynn Hecht Schafran, The Smurfette Principle, NY Times 6-12 (Apr 28, 1991).

264 Id.

${ }^{166}$ Bill Carter, Children's TV, Where Boys Are King, NY Times A1 (May 1, 1991).

${ }_{168}$ Katha Pollitt, The Smurfette Principle, NY Times 6-22 (Apr 7, 1991).

167 Id. 
tance of physical appearance for girls. ${ }^{188}$ Children's video games are worse: when female humans appear, which is rare, they are in need of rescue by the male hero. Female figures in such games are rarely active. ${ }^{169}$

American media, particularly television, film, and video games, promote violence. Most of the empirical evidence on the effect of television and film violence indicates that it stimulates, rather than purges, aggression. ${ }^{170}$ Media violence almost always takes place in the context of stereotypical sex roles. It is rare for a woman to use violence other than as an agent of a man or as a crazy person. Military video games present military activities in an abstract context, without blood or pain or suffering. The military use video "games" as training devices, and civilians use them as recreational activities. $^{171}$

As a result of free speech in the media-as well as sexist speech elsewhere in the culture-women face three problems. First, the media silences women. This is true on the most literal level. For example, whether in news, sports, or other programs, it is overwhelmingly men who speak on television. When women do speak, they usually speak others' words rather than their own. And when women are authorities, they tend to espouse anti-women positions. ${ }^{172}$

The media free market is not a market without censors, though the censors are not governments. Women's speech is censored directly by media executives and by advertisers who control the substantive content of articles and programs in magazines and on television. ${ }^{173}$ Women's speech is censored indirectly by media 1991):

${ }^{168}$ See Butler and Paisley, Women and the Mass Media at 150-51 (cited in note 151).

${ }^{169}$ Eugene F. Provenzo, Jr., Video Kids: Making Sense of Nintendo 61 (Harvard,

In a sample of 100 video arcade games, [Terri] Toles determined that 92 percent of the games did not include any female roles, and that of the remaining 8 percent of the games, 6 percent had females assuming "damsel in distress" roles and 2 percent in active roles. Interestingly, in the case of the two females who do take active roles, neither is human-one being a Mama Kangaroo attempting to retrieve her child and the second a feminized blob, Ms. Pac-Man.

${ }^{170}$ See, for example, L. Rowell Heusmann and Neil M. Malamuth, Media Violence and Antisocial Behavior: An Overview 42(3) J Soc Issues 1 (1986).

${ }^{171}$ Provenzo, Video Kids at 132-35 (cited in note 169); Terri Toles, Video Games and American Military Ideology, in Vincent Mosco and Janet Wasko, 3 Critical Communications Review: Popular Culture and Media Events 207, 217-21 (Ablex, 1985).

${ }^{172}$ See text accompanying note 155.

${ }^{173}$ See Sunstein, 59 U Chi L Rev at 282 (cited in note 2); Gloria Steinem, Sex, Lies \& Advertising, Ms. 18 (Jul/Aug 1990). 
portrayals of feminists as irrational, unattractive, man-hating lesbians. ${ }^{174}$

Second, market speech harms women more than men by impeding women's ability to develop as autonomous individuals. In a world of inequality, where men control a disproportionate share of resources and women have a disproportionate need for resources because of their responsibility for children, it often pays for women to present themselves as attractive sex objects. But women also internalize the beauty standard and judge themselves inadequate. In a 1984 Glamour survey, seventy-five percent of women between the ages of eighteen and thirty-five believed they were fat, though only twenty-five percent were fat by medical standards. More "heartbreaking," and a greater barrier to women's autonomous selfhood, "respondents chose losing ten to fifteen pounds above success in work or in love as their most desired goal." ${ }^{175}$ Because of the implicit and explicit messages they receive about their abilities and worth, women have lower self-esteem and confidence than men. Pornography teaches women through concrete physical experience and example that they are worthless and that they exist to service men.

The third problem for women is the media focus on violence and its glorification. This culture of violence is alien to more women than men. Men use violence against women more than women use it against men. ${ }^{176}$ The media's glorification of violence, together with the video-game mentality visible during the Gulf War, encourages citizens to view United States military aggression as a spectator sport, one in which men dominate.

These problems exist not only for American women but also for women throughout the world, given the high levels at which we export American media. People in other cultures viewing western media are likely to associate feminism with the pervasive images of women in western media, and hence with the sexualization of women. As a result, women in other cultures encounter more difficulty in objecting to their status; they can easily be tarred as "feminists," decadent as well as disloyal because western. American media thus silences women in other societies, forcing them to betray

\footnotetext{
${ }^{174}$ See Paula Kamen, Feminist Fatale: Voices from the "Twentysomething" Generation Explore the Future of the "Women's Movement" 63-74 (Donald I. Fine, 1991).

175 Wolf, The Beauty Myth at 185-86 (cited in note 158).

${ }^{176}$ See text accompanying notes 170-71.
} 
either their sex or their culture. ${ }^{177}$ In addition, the allure of western glamor makes it more difficult for many women and girls to become autonomous selves, rather than the playthings western media suggests women are. ${ }^{178}$

These problems impede women's political success in the United States and elsewhere. "Free" speech in a market means that those with the ability to pay are able to speak the most. This is true for political speech. Women are poorer than men and have greater economic responsibility for children. These realities mean men have more disposable income to spend on political speech. Current case law constitutionally protects this differential. ${ }^{179}$

Speech and effective communication are necessary preconditions for having one's needs recognized in the political process. Low self-esteem compounds this differential, since it translates into feelings that one is not entitled to more. ${ }^{180}$ Particularly in an individualistic culture such as the United States, low self-esteem and feelings of disentitlement impede solutions which must be both structural and political, such as the support systems women need and enjoy in the rest of the North Atlantic community of nations. ${ }^{181}$

The media's cultivation of violence also has political effects. Women oppose violence more than men do; the glorification of violence impedes action to suppress it, such as passage of gun control legislation or refusal to go to war.

The reader may object that the Free Speech Clause protects feminist speech today just as it protects other speech, and that

177 See, for example, Leila Ahmed, Feminism and Feminist Movements in the Middle East, A Preliminary Exploration: Turkey, Egypt, Algeria, People's Democratic Republic of Yemen, in Azizah al-Hibri, ed, Women and Islam 153, 162 (Pergamon Press, 1982).

${ }^{17}$ One writer has noted that the combination of Western exports of media violence and weaponry to third world countries "satiate[s] the Third World in patterns of brutality." Sissela Bok, Alva Myrdal: A Daughter's Memoir 346 (Addison-Wesley, 1991). In A Daughter's Memoir, Bok discusses her mother's acceptance of the Nobel Peace Prize in 1982. The speech discusses these themes generally. See Alva Myrdal, Disarmament, Technology and the Growth in Violence, reprinted in Les Prix Nobel 1982: Nobel Prizes, Presentations, Biographies and Lectures 222, 228 (Acmquist \& Wiksell, 1983).

${ }^{179}$ Buckley $v$ Valeo, 424 US 1 (1976) (invalidating campaign expenditure ceilings, ensuring that those with more funding have a larger political voice).

${ }^{180}$ See Linda Gordon, What Does Welfare Regulate?, 55 Soc Res 609, 623 (1988):

Women's movements have had a particularly erratic, discontinuous history. This is because women's sense of entitlement is tenuous, easily reinterpreted as selfish, women being raised to define their virtue in terms of selflessness.

181 See, for example, Sylvia Ann Hewlett, When the Bough Breaks: The Cost of Neglecting Our Children 173-82 (Basic, 1991); Sheila B. Kamerman and Alfred J. Kahn, What Europe Does for Single-Parent Families, 93 Pub Int 70 (Fall 1988). 
without this protection, women pressing for change would be worse off. But a comparison of government censorship of feminist speech in England and the United States suggests that the American Free Speech Clause is not the critical factor when feminist speech is permitted. England has no written constitution and hence no Free Speech Clause. Historically, both England and the United States censored much feminist speech, even simple information about birth control, during the nineteenth and early twentieth centuries. ${ }^{182}$ Neither country's government censors private feminist speech. The United States, however, does censor some feminist speech today: doctors receiving certain federal funding cannot mention abortion to a pregnant woman, even when abortion is the safest available treatment. ${ }^{183}$ This comparison suggests that the source of government's unwillingness to censor private feminist speech is not the Free Speech Clause.

The Free Speech Clause does not, in and of itself, cause the problems "free" speech creates for women. England, for example, has no Free Speech Clause and yet has sexist speech. My main point is that the Free Speech Clause does more for men than for women, protecting speech that supports patriarchy. In addition, the Free Speech Clause impedes needed reform. It makes many direct forms of regulation of sexist speech unconstitutional. It also gives constitutional legitimacy to opponents' arguments even when the Constitution might not bar such reform.

I suggest a number of ways in which we could interpret or amend the Free Speech Clause to avoid or lessen the problems discussed in this Section. We could redefine or amend the Free Speech Clause to allow more equitable limits on spending for political speech. ${ }^{184}$ The Free Speech Clause could be redefined or amended to allow government to regulate speech in ways suggested by Andrea Dworkin, Catharine MacKinnon, Mari Matsuda, and Cass Sunstein. For example, Dworkin and MacKinnon would give those harmed by pornography a right to damages. ${ }^{185}$ Matsuda suggests that the United States should limit racist hate speech, as do

${ }^{182}$ Elizabeth Barrett Browning was censored in the United States (Boston) and England. Contraceptive information was banned in both countries. Anne Lyon Haight, Banned Books: Informal Notes on Some Books Banned for Various Reasons at Various Times and in Various Places 49, 63-64, 74-75, 77 (Bowker, 1970).

${ }^{183}$ See Rust $v$ Sullivan, 111 S Ct 1759, 1767 (1991).

184 This interpretation would necessarily overrule Buckley, 424 US 1.

185 See Andrea Dworkin and Catharine A. MacKinnon, Pornography and Civil Rights: A New Day for Women's Equality 139-41 (Dworkin/MacKinnon, 1988) (model antipornography ordinance). 
other liberal democracies (including England). ${ }^{186}$ Sunstein suggests that government intervention should be permissible if it does not abridge speech but rather expands the market in speech by subsidizing or otherwise enabling speech that would not otherwise be heard. ${ }^{187}$ Under Sunstein's "New Deal for Speech," for example, it might be permissible for the FCC to take sexism or ownership by women into account in licensing. ${ }^{188}$ In addition, Sunstein suggests that the free speech principle should be understood to be centered above all on political deliberation. ${ }^{189}$ Under this approach, other forms of speech may be regulated for illegitimate reasons, but on the basis of a lesser showing of harm. ${ }^{190}$

Perhaps we should amend the Bill of Rights to make such reform seem possible. The African National Congress (ANC) draft Bill of Rights, for example, includes both a free speech provision ${ }^{191}$ and a provision that "[e]ducational institutions, the media, advertising and other social institutions shall be under a duty to discourage sexual and other types of stereotyping." ${ }^{192}$ In addition, the ANC draft Bill of Rights includes an affirmative action provision that would seem to permit government funding of, or preferences for, women's speech or nonsexist speech, ${ }^{193}$ and another authorizing restrictions of racist or sexist speech. ${ }^{194}$

In this Section, I have discussed problems that "free" speech in a market economy poses for women. Women are silenced.

${ }_{186}$ Mari J. Matsuda, Public Response to Racist Speech: Considering the Victim's Story, 87 Mich L Rev 2320, 2346-47, 2380-81 (1989).

${ }_{187}$ Sunstein, 59 U Chi L Rev at 267-69 (cited in note 2).

${ }^{18}$ See Metro Broadcasting, Inc. v FCC, 110 S Ct 2997 (1990) (upholding constitutionality of requirement that transfers of certain "distress sale" licenses go to minority-controlled firms). The example is mine, rather than Sunstein's, and he might not agree.

28s Sunstein, $59 \mathrm{U}$ Chi L Rev at 301 (cited in note 2).

190 Id.

192 African National Congress, A Bill of Rights for a Democratic South Africa-Working Draft for Consultation, Art 4, § 1 (on file with U Chi L Rev) ("There shall be freedom of thought, speech, expression and opinion, including a free press which shall respect the right to reply.").

192 Id at Art 7, § 5.

${ }^{193}$ Id at Art $13, \S 1$ ("Nothing in the Constitution shall prevent the enactment of legislation, or the adoption by any public or private body of special measures of a positive kind designed to procure the advancement and the opening up of opportunities, including access to education, skills, employment and land, and the general advancement in social, economic and cultural spheres, of men and women who in the past have been disadvantaged by discrimination.").

194 Id at Art 14, $\$ 4$ ("... the State may enact legislation to prohibit the circulation or possession of materials which incite racial, ethnic, religious, gender or linguistic hatred, which provoke violence, or which insult, degrade, defame or encourage abuse of any racial, ethnic, religious, gender or linguistic group."). 
Women have difficulty developing as autonomous selves with as much confidence as men. And women live in a culture permeated by male violence. I have suggested a number of reforms that should be considered. If the First Amendment cannot be interpreted to allow such reforms, we should consider changing it, since the problems impede women's ability to participate effectively in the political system.

\section{The Right to Bear Arms}

The drafters of the Constitution saw the ability of armed citizens to oppose national government as an important check on the misuse of federal governmental power, with its "standing army of lackeys and hirelings (mercenaries, vagrants, convicts, aliens, and the like)." 195 The Second Amendment to the Constitution guarantees "the right of the people to keep and bear Arms." amendment has one of three meanings: either it grants states the right to organize citizens into state militias, or it grants individual citizens the right to bear arms (against the state and one another), or it grants both. ${ }^{197}$ Each of these readings is troubling from the perspective of women.

\section{A. State Militias}

One reading of the Second Amendment is that it limits the ability of the federal government to limit state militias: citizens have the right to bear arms for the state. ${ }^{198}$ But the right of states to organize militias of citizens has meant that only men may bear arms in military organizations, even after women received the vote and became, one might have thought, full citizens. ${ }^{199}$ Women are still forbidden to bear arms in combat units, both in state militias and in the national armed services; women may serve in the militia

195 Akhil Reed Amar, The Bill of Rights as a Constitution, 100 Yale L J 1131, 1163 (1991).

186 US Const, Amend II.

197 Wendy Brown, Guns, Cowboys, Philadelphia Mayors, and Civic Republicanism: On Sanford Levinson's The Embarrassing Second Amendment, 99 Yale L J 661, 662 (1989); Sanford Levinson, The Embarrassing Second Amendment, 99 Yale L J 637, 644-45, 648-51, 655-56 (1989); John E. Nowak, Ronald D. Rotunda, and J. Nelson Young, Constitutional Law $\$ 10.2 \mathrm{n} 4$ (West, 3d ed 1986). Elaine Scarry has argued that the right of citizens to bear arms is inconsistent with the use of nuclear weapons. Elaine Scarry, War and the Social Contract: Nuclear Policy, Distribution, and the Right to Bear Arms, $139 \mathrm{U}$ Pa L Rev 1257 (1991).

${ }^{188}$ Levinson, 99 Yale $L J$ at 644-45 (cited in note 197); Brown, 99 Yale L $J$ at 661-62 (cited in note 197).

199 See Amar, 100 Yale L J at 1202-03 (cited in note 195). 
and federal services only in limited numbers and in limited positions. $^{200}$

Were women fully integrated in combat units in state militia, they would almost certainly serve in combat when state units are called up to fight at the federal level during national emergencies, given the integrated structure of the military. The state militia, together with the national army, navy, marines, and air force, form the United States military. Both the state militia and national armed services are delineated in Article I of the Constitution. It mentions the "organized"201 state militia (or national guards) and the federal armed services. The state National Guards are under the command of the governors ${ }^{202}$ unless called into the service of the United States by the President pursuant to his power under Article II, $\S 2 .{ }^{203}$ The Congress has the power to organize, arm, and discipline the state militia (National Guard) and to govern "such Part of them as may be employed in the Service of the United States." 204 But the states have the reserved power to appoint officers to the militia (National Guard) and to train them "according to the discipline prescribed by Congress." In addition, Congress and the President have the power to raise and deploy federal armies. At the drafting of the Bill of Rights, the militia referred to male citizens drafted at the local or state level (citizen-soldiers) and the federal armies referred to volunteers (mercenaries). ${ }^{205}$

When the United States engages in war, the state National Guards are routinely called and integrated into active forces, both combat and noncombat. National Guard units served in World War I, World War II, the Korean War, Panama, ${ }^{206}$ and the Gulf War. National Guard units have often played heroic roles in for-

${ }^{200}$ See, for example, Women in Uniform, Boston Globe 3 (Jun 19, 1991) ("Women constituted 11 percent of U.S. armed forces as of December 1990"); Letters to the Editor USA Today 11A (Jul 2, 1991) (52\% of Army jobs open to women; $97 \%$ of Air Force jobs; $59 \%$ of Navy jobs; $20 \%$ of Marine jobs).

201 There is also the unorganized militia, but it does not seem to be of any practical importance today. The unorganized militia is defined in the United States Code as consisting "of all able-bodied males" 17 to 44 who are, or have declared their intent to be, citizens of the United States unless they are members of the organized militia or of the federal armed forces. 10 USC $\S \S 311,312$ (1991).

${ }^{202}$ Richard Halloran, With Roots in State and in Past, Guard Has Many Missions, NY Times A16 (Aug 23, 1988).

${ }_{203}$ US Const, Art II, § 2. Article I, § 8 provides that Congress cannot appropriate money for the army "for a longer Term than two Years."

204 US Const, Art I, § 8.

205 Amar, 100 Yale L J at 1168 (cited in note 195).

${ }^{206}$ Halloran, NY Times at A16 (cited in note 202); Rudy Abramson, U.S. Again Looks to the Reservists, LA Times A1 (Aug 23, 1990) (only a few National Guard units served in 
eign wars. For example, in World War I, the earliest troops in combat, and those who saw the most combat, were National Guards, including the famous " $42 \mathrm{~d}$ (Rainbow) Division composed of Guard units from many states, including the 69th Infantry Regiment from New York."207 The government mobilized the National Guards for World War II prior to any draft, and over a year before the country entered the war. Many played important combat roles. For example, the 38th Infantry Division fought in the Philippines. ${ }^{208}$ Today, the reserves play a central role in defense strategy. They are an integral part of any fighting force, capable of being quickly deployed and integrated with active troops, as illustrated by past wars. ${ }^{209}$ Thus the full integration of women into the National Guard would mean full integration into the federal forces unless the various branches reorganized to limit women's integration into combat. That should be impermissible if women have a right to be treated as full citizen-soldiers.

As Akhil Amar has noted, militia service, along with jury service and voting, are political rights and obligations of citizens in a democracy. ${ }^{210}$ Exclusion of women from militia service in combat denies women the obligations of full citizenship. This denial inevitably translates into disadvantaging women as citizens by depriving them of power they would otherwise share more equally with men. I discuss two concrete problems for American women.

First, keeping women out of combat maintains the image of the male warrior, who is superior to physically passive women who need his protection and cannot resist his violence. ${ }^{211}$ This is important on many levels: in terms of the effect of these images on the culture in general and in terms of the lives of individual women and men. The military trains men to operate within a macho culture with the belief that they are superior to women. New male recruits are called "girls" and "ladies" until they earn a masculine label. ${ }^{212}$ They march to a sexist and racist cadence: "I don't know

\footnotetext{
Vietnam, in part because of a perceived need to keep them available in the event they were needed in Europe).

${ }^{207}$ Halloran, NY Times A16 (cited in note 202).

${ }^{208}$ Id (this is the unit in which Vice President Quayle later served).

${ }^{208}$ Abramson, LA Times 1A (cited in note 206).

${ }^{210}$ See Amar, 100 Yale L J at 1202-03 (cited in note 195); Kenneth L. Karst, The Pursuit of Manhood and the Desegregation of the Armed Forces, 38 UCLA L Rev 499, 499-500 (1991).

211 See generally Karst, 38 UCLA L Rev 499 (cited in note 210).

${ }^{212}$ Christine L. Williams, Gender Differences at Work: Women and Men in Nontraditional Occupations 69 (California, 1989).
} 
but I've been told, Eskimo pussy is mighty cold."213 They learn about venereal diseases from "Suzy Rottoncrotch."214 Pictures of nude women are common. ${ }^{215}$ In the late 1980s, Marine recruits at Parris Island, South Carolina, marched behind a sign with a naked woman on it and another with a skull and crossbones and the words "kill, rape, pillage, burn." 216 The boys and men trained in this system interact with women both within and outside the military. Men who chant these cadences and learn to consume pornography in the military become husbands, fathers, employees, employers, voters and politicians. Their experiences in the military are likely to make them less willing to accept women as leaders or to sympathize with the problems of women constituents.

The other side of this coin is that keeping women out of combat positions in the military supports the taboo against women using force, especially lethal force. The socialization of girls and women encourages them to be less physically aggressive than boys and men, and boys and men are socialized to expect girls and women to be passive in response to their violence. ${ }^{217}$ It is revealing that current military rules do not exclude women from combat zones (i.e., do not keep women out of danger), but rather keep women from using lethal force. ${ }^{218}$ Maintaining male control of le-

213 Id.

214 Id.

${ }^{215}$ Id. The author of this study reports that "[i]n the lounge of the student squadron where I interviewed female pilots, pictures of nude women and 'Playboy' insignias were tacked on the walls." In civilian life, such workplaces would constitute sexual harassment. See, for example, Ellison v Brady, 924 F2d 872 (9th Cir 1991); Robinson v Jacksonville Shipyards, Inc., 760 F Supp 1486 (M D Fla 1991).

${ }_{216}$ Marines' 'rape' slogan draws fire, Wisc State J 7A (Oct 4, 1989).

${ }^{217}$ See Williams, Gender Differences at Work at 54 (cited in note 212) (policies that prohibit women from direct combat but expose them to indirect combat constitute a male protection racket); Pauline Burt and Patricia O'Brien, Stopping Rape: Successful Survival Strategies (Pergamon, 1985) (study of many connections between passivity and rape). See also Jalna Hanmer and Elizabeth Stanko, Stripping Away the Rhetoric of Protection: Violence to Women, Law and the State in Britain and the U.S.A., 13 Intl J Soc L 357, 370 (1985) ("Essentially women in today's society are caught in a bind; male violence to women forces women to turn to men for protection.").

${ }^{218}$ See Williams, Gender Differences at Work at 54 (cited in note 212). During the Panamanian invasion, women drove other soldiers under sniper fire and one woman, Captain Linda Bray, led a military police company in a firefight. 2 Army Women Being Investigated for Disobeying Order in Panama, NY Times A20 (Jan 21, 1990). An uproar followed over whether in fact Captain Bray had led troops in combat (in violation of military rules) and whether women should be allowed in combat positions. There was, however, no discussion of whether women should be kept out of combat zones as long as in noncombat positions, such as driving under sniper fire. See, for example, Tony Kornheiser, Capt. Bray and a Dogged Assault, Wash Post D1 (Jan 12, 1990); Judy Mann, The Battle Has Just Begun, Wash Post C3 (Jan 5, 1990). Several enlisted women in the military police were also in 
thal force clearly preserves male interests both with respect to control of the military itself (a powerful institution in its own right) and with respect to men's power over women through physical intimidation throughout society.

Integrating women into the military would change the way we raise girls and decrease male violence against women. We treat girls and boys differently even as infants and children. As babies, boys are more likely to be tossed about. We expect boys to be tough and not to cry. We treat girls as more physically vulnerable and expect them to be less active physically. Girls' sports programs are different from boys': serious girls' sports are rarely aggressive contact team sports. Were women present in the military and in combat positions in proportion to their presence in the population, we probably would treat girls differently. There probably would be less violence against women, because women would be less passive physically and because military training would be less sexist. There is, for example, evidence that men who are or have been in the military are more likely to batter their wives. ${ }^{219}$ Were women and men trained in the same system, they would be more likely to interact as equals elsewhere.

Women's exclusion from combat units in the military also increases the rate at which our soldiers rape women from the "other" side during war. ${ }^{220}$ Our soldiers would be less likely to rape if half their comrades were women. Although we do not tend to hear much about this problem, it does happen many times in most wars. ${ }^{221}$ We should consider it in assessing the costs and benefits of including women in the military.

The second major problem, and an extremely troubling one in a democracy, is that the exclusion of women from the draft and from combat positions in state militia and federal forces supports many barriers, erected by government itself, to women's participation in government and political life. The exclusion of women from combat means that women have less authority in government than

combat attacking Panamanian defense headquarters, thus raising controversy. See Wilson Ring, Women Led U.S. Troops into Battle; Captain's Platoon Took PDF Target, Wash Post A1 (Jan 3, 1990); Molly Moore, Combat Role to be Sought for Women; Panama Experience Prompts Schroeder, Wash Post A25 (Jan 4, 1990). See also Colman McCarthy, Women at War, a Foolish First, Wash Post F2 (Jan 14, 1990) ("What kind of society are we when similar opportunity in killing is the standard for equality.").

- ${ }^{219}$ See Del Martin, Battered Wives 52-53 (Glide, 1976); Walker, The Battered Woman at 36-37 (cited in note 52).

220 Susan Brownmiller, Against Our Will: Men, Women and Rape 64-65 (Simon \& Schuster, 1975).

221 Id at 31-32. 
men. Because of the exclusion, only men can be military heros. Women political candidates cannot boast of combat service, which voters regard as a credential for public office. Women within legislative bodies are regarded as having less authority on military matters than their male colleagues because they have not "been there;" they are regarded as less qualified to serve on military oversight committees and as having less authority if on such committees.

The military services deny women equal employment opportunities because they both limit the numbers of women in the services, and they deny women the combat experience necessary for promotion to high rank. Because they are so often present in token numbers, women in the services are subject to more sexual harassment than they would be in a more integrated organization. ${ }^{222}$ No woman has ever been a member of the Joint Chiefs of Staff. Nor is any woman likely to be as long as women are not present in the military, in all positions, in proportion to their presence in the population.

It may be that women are more pacifist than men. If so, excluding women from combat disarms women's pacifism. Their resistance means less because it has fewer consequences. For example, women protesting the war in Vietnam had less authority because they did not have draft cards to burn and tended therefore (and for -a host of other reasons) to be relegated to subservient positions in anti-war organizations. ${ }^{223}$ Women in Congress who oppose military action have less authority because they have not been in combat. They, unlike Senator Kerrey, cannot oppose a military action with the authority of a recipient of the Congressional Medal of Honor who has lost a leg in combat.24

In addition, both federal and state governments have created a large number of preferences for veterans. Under these preferences, many positions in state and federal government are held mostly by men. For example, proportionately, even fewer federal administra-

222 Karst, 38 UCLA L Rev at 525 (cited in note 210); Susanne Fowler, Breaking Ranks: Rape, Harassment Claimed by Cadets Chi Trib Womanews 1 (Oct 20, 1991) (allegations of sexual harassment in military training program at Texas A\&M).

${ }^{223}$ Sara Ruddick has examined many of the arguments for including women in the military to serve peace and concludes that this is an inappropriate strategy because such interests can best be "cultivated in pacifist organizations." See Sara Ruddick, Pacifying the Forces: Drafting Women in the Interests of Peace, 8 Signs 471, 485-86 (1983). But, as Jennifer Hertz pointed out to me, Ruddick ignores the ways in which women's exemption from combat "disarms" them within pacifist organizations and denies them the same authority as pacifist men who have so much more to lose by resistance to military service.

${ }^{224}$ John Cassidy, Democrats Run for Cover as Bush Fever Grips US, Sunday Times 14 (London) (Mar 17, 1991). 
tive law judges are women (5.41 percent) than federal Supreme Court (11.11 percent), federal Courts of Appeal (10.11 percent), or federal District Court judges (8.69 percent) because the federal veterans' preference applies to administrative law judges. ${ }^{225}$ In many states, there are preferences for veterans in state employment as well. ${ }^{226}$ Some state governments are almost entirely male at high levels for the same reason. ${ }^{227}$ Thus, as a result of discrimination in military service, women are less likely to wield governmental power in nonelective offices. ${ }^{228}$

The reader may object that paying for military service is a valid governmental purpose, and that veterans' preferences are simply one form of compensation. But veterans' preferences for governmental employment are not the equivalent of compensation schemes. Such preferences give men an edge in running government and exclude women from power on the basis of a factor linked by government itself to sex. In addition, such policies are anti-democratic, creating a government based on a sort of military aristocracy rather than a government open to all.

I have discussed two ways in which the exclusion of women from combat hurts women. The exclusion contributes to cultural images and the social reality of violent male warriors and physically passive women in need of their protection. It also creates numerous barriers to women's participation in government and political life. As the framers of the Second Amendment realized, "ultimate political power" lies "with those who control the means of force."229

There are, of course, a number of arguments that can be made against full integration of women into the armed services and $\mathrm{Na}$ tional Guard. Most women, even most women in the military today, oppose mandatory combat service. Most career military

${ }^{225}$ The data on women judges is based on a phone call to Dixie Noble, National Association of Women Judges, Williamsburg, Virginia (Oct 3, 1991) (notes on file with U Chi L Rev). 5 USC $\$ 3105$ (1991) authorizes agencies to appoint administrative law judges; 5 CFR $\$ 930.203(\mathrm{e})$ (1990) instructs that agencies should accept highest rated applicants for Administrative Law Judge positions "augmented . . . by veteran preference."

${ }^{226}$ Veterans' organizations also receive postal subsidies denied to women's organizations. 39 USC $\S 3626$ (1991).

${ }_{227}$ See, for example, Personnel Administrator of Massachusetts v Feeney, 442 US 256, 283 (1979) (Marshall dissenting) (majority upheld veterans' preferences in Massachusetts despite fact that $98 \%$ of veterans were male and virtually all desirable state civil service employment positions were consequently held by men).

${ }^{228}$ See id (as a result of Massachusetts's preference for veterans, "desirable state civil service employment [is] an almost exclusively male prerogative").

${ }^{229}$ David C. Williams, Civic Republicanism and the Citizen Militia: The Terrifying Second Amendment, 101 Yale L J 551, 553 (1992). 
women want to engage in combat service, but ordinary enlisted women do not. ${ }^{230}$ The military is perhaps the most masculinist institution in our society; its values and its focus on physical violence are alien to most women. Nevertheless, until women are full citizens-citizen soldiers on the same basis as men-women will have less power in government and outside it. They will lack power in waging peace as well as war, and will face restricted employment opportunities both in the military and in government.

Today's interpretation of the Bill of Rights does not require that women be accorded full citizenship. We should interpret the Second Amendment, especially in light of the Fourteenth and Nineteenth Amendments, as extending the right to bear arms in state militia to women. At a minimum, the Fourteenth Amendment should bar veterans' preferences in state employment as long as women do not receive equal treatment in the military. It is absurd to regard injury as justifying injury as when overt government discrimination against women in one area justifies non-merit based standards that exclude most women from many government jobs.

\section{B. The Right of Individual Citizens to Bear Arms}

The other possible meaning of the Second Amendment, either as an alternative reading or in combination with the reading given above, ${ }^{231}$ is that it limits the ability of both the state and federal governments to regulate gun ownership. In other words, it grants individuals a right to bear arms, arms which may be used, perhaps illegally, against other individuals or the state. ${ }^{232}$ Although it is extremely difficult to compare rates of violence internationally because of reporting differences, the United States is clearly much

${ }^{230}$ Most (about $75 \%$ of those interviewed by one reporter in Panama) female officers believed that women should be able to volunteer for combat. But only a quarter of that sample thought "that women should be compelled to enter combat units, just as men are." Charles Moskos, Army Women Atlantic Monthly 7, 77 (Aug 1990). In contrast, about 75\% of enlisted women thought that women should not be allowed into combat. Only $25 \%$ thought that women should be able to volunteer for combat. No enlisted women "favored forcing women into combat assignments." Id.

${ }^{231}$ Amar argues, as noted earlier, that the Second Amendment means both the right of the individual citizen to bear arms and of the states to organize their citizens into militia. See Amar, 100 Yale L J at 1162-73 (cited in note 195).

${ }^{232}$ Although it is not clear whether the Second Amendment would ban legislation banning private ownership of guns (see, for example, Levinson, 99 Yale L J at 640 (cited in note 197)), the Second Amendment does appear to make even regulation more difficult, by giving those who want guns to remain unregulated a constitutional argument and rallying cry. 
more violent than other countries. ${ }^{233}$ Although there is no way to prove this point, it seems likely that the Second Amendment reflects and reinforces the unusual levels of violence in our culture. Moreover, violence harms women and other groups more than it harms men like the founding fathers.

Violence devastates poor inner city communities, which are made more deadly by the availability of guns. Women in the inner cities where crime is highest lead lives circumscribed by violence. Intolerable levels of violence victimize them and those they love. They must worry before going outside at night, or even during the day in some areas. ${ }^{234}$ They worry about their children getting safely through the school day and back home. Many see their sons join the violent underworld of drugs and gangs with deadly results: "[T] tween the ages of fifteen and twenty-four is murder."235 Men like the founding fathers-propertied white men-do not live in these neighborhoods and are not as likely to be victims or perpetrators of violence as are poor women and men.

To the extent the Second Amendment protects individuals' rights to own guns, or assists the NRA in resisting effective gun control legislation, the Second Amendment is a countermajoritarian impediment to women's effective use of the political system. Men are not only more likely to own guns than women, they are also more likely to oppose gun control. ${ }^{236}$ For example, in 1985, fifty percent of men but only twelve percent of women owned guns. $^{237}$ In 1986, fifty-five percent of women, but only thirty-nine percent of men, favored laws banning the sale and possession of handguns in their own community. ${ }^{238}$ Women and men have conflicting interests and opinions concerning gun regulation, and the Constitution enshrines, at least on a rhetorical level, a male norm. ${ }^{239}$

${ }^{233}$ See, for example, James D. Wright, et al, Weapons, Crime, and Violence in America: A Literature Review and Research Agenda 2-4 (US Dept of Justice, 1981).

${ }^{23+}$ Margaret T. Gordon and Stephanie Riger, The Female Fear 8-22 (Free Press, 1989).

${ }^{235}$ Randolph N. Stone, Crisis in the Criminal Justice System, 8 Harv BlackLetter J 33, 39 (1991).

${ }^{236}$ Katherine M. Jamieson and Timothy J. Flanagan, eds, Sourcebook of Criminal Justice Statistics 109-11, Tables 2.38-2.43 (US Dept of Justice, 1987).

${ }^{237}$ Id at 109 , Table 2.38 .

${ }^{238}$ Id at 110 , Table 2.43 .

${ }^{239}$ See Brown, 99 Yale L Rev at 663-64 (cited in note 197). For evidence that gun control laws can decrease violence, see Elisabeth Scarff, Evaluation of the Canadian Gun Control Legislation: Final Report 36, 39, 42, 53, 63, 65, 66, 68 (Ministry of the Solicitor General of Canada, 1983); Gun Control Laws in Foreign Countries 88-94, 135-36, 157-60 (Law Li- 
Changes to the Second Amendment in light of my criticisms are easy to imagine. An amendment or new interpretation could allow effective national bans on gun ownership by individuals. Alternatively, if the Second Amendment affords citizens the right to bear arms in state militia, that right should be extended to all citizens, regardless of sex.

\section{Criminal Justice System Protections}

The Bill of Rights contains a number of provisions designed to guard against governmental misuse of the criminal justice system. The Fourth Amendment proscribes unreasonable searches and seizures. ${ }^{240}$ The Fifth Amendment provides for indictment by a grand jury for serious crimes and for due process in criminal trials. ${ }^{241}$ The Sixth Amendment guarantees the accused a right to a trial by jury in criminal cases, and the assistance of counsel for his defense. ${ }^{242}$ The drafters intended these provisions to guard against misuse of the criminal justice system by government, particularly criminal prosecution of government critics. ${ }^{243}$

Nothing in the Bill of Rights or the Fourteenth Amendment guards against systemic racism in the operation of the criminal justice system, or against its systematic misuse to "solve" problems associated with racism and poverty. In making these points, the emphasis in this section differs somewhat from the emphasis in other sections. Here, I stress that the Bill of Rights does less for poor minorities than it does for propertied white men. In other sections, I stress that the Bill of Rights does less for women than for men. This shift is appropriate even though my major concern is the latter. Although most of those caught in the criminal "justice" system are men, the problems with the way the system operates in poor minority communities pose major problems for women in those communities. One cannot separate the interests of poor minority women and men; their fates are intertwined in ways without precise parallel to white women and men, particularly propertied white women and men. Women who live in communities destroyed by drugs and by the "war" on drugs are devastated by the destruc-

brary, Library of Congress, 1981) (evidence from Britain mixed, but both Japan and Sweden, which have strict gun control laws, have low rates of murders involving firearms).

240 US Const, Amend IV.

241 US Const, Amend V.

242 US Const, Amend VI.

${ }^{243}$ Amar, 100 Yale L J at 1175-99 (cited in note 195). 
tion around them even though they themselves are less likely to go to prison than are their sons, lovers, and husbands.

At the time the Bill of Rights was enacted, whites were free to enter the home and batter, rape, or kill African Americans with impunity. This was particularly true for African Americans who were slaves, but even free or freed African Americans were often subject to white violence without the criminal law protection afforded white men (and white women in some contexts). ${ }^{244}$ At the same time, black people, particularly slaves, were often punished for alleged crimes without any evidence of guilt. For African Americans in 1791, the criminal "justice" system was part of the problem, and the Bill of Rights did nothing to end these systemic abuses.

Racism persists within the criminal justice system. ${ }^{245}$ African American women receive less protection from the criminal justice system than white women. When African American women are raped, their rapists are less likely to serve time than the rapists of white women. ${ }^{246}$ Defendants in rape prosecutions often succeed by suggesting that the woman was a prostitute, and this may be especially effective when women live, as poor and African American women often must, in neighborhoods where prostitutes are on the streets. African Americans, women as well as men, more often fall into the police net because they fit the drug courier image, ${ }^{247}$ are more likely to be treated roughly or beaten severely by the police, ${ }^{248}$ and are more likely to be arrested. States are most likely to

${ }^{244}$ See, for example, State $v$ Weaver, 3 NC 70, 71 (1798) (justifiable homicide for master to kill slave or freed servant who forcefully resists master's use of force to compel obedience).

${ }^{245}$ I only outline problems in the criminal justice system here. I am not an expert in criminal law and cannot provide the in-depth discussion these issues deserve. For a fuller discussion of these problems, I refer the reader to work by others. Stone, 8 Harv BlackLetter L J 33 (cited in note 235); Stephen J. Schulhofer, Access to Justice for the American Underclass, The World \& I 463, $469-75$ (Jun 1991); Sheri Lynn Johnson, Unconscious Racism and the Criminal Law, 73 Cornell L Rev 1016 (1988); Randall L. Kennedy, McCleskey v. Kemp: Race, Capital Punishment, and the Supreme Court, 101 Harv L Rev 1388 (1988); Samuel R. Gross, Race and Death: The Judicial Evaluation of Evidence of Discrimination in Capital Sentencing, 18 UC Davis L Rev 1275 (1985).

248 Generalized from data that finds that black offenders are sentenced most harshly when their victims are white, Alfred Blumstein, et al, eds, 1 Research on Sentencing: The Search for Reform 101 (National Academic Press, 1983). See also Gary D. LaFree, The Effect of Sexual Stratification by Race on Official Reactions to Rape, 45 Am Soc Rev 842, 852 (1980).

247 Editorial, Bringing Sanity to Seizure Laws, Chi Trib 2 (Sep 1, 1991).

${ }^{248}$ See, for example, Frank Clifford and John L. Mitchell, Incident Gives City a National Black Eye; Image: Old Memories of Free-Swinging Cops Are Revived, LA Times B1 (Mar 7, 1991) (reporting on Rodney Glen King police beating incident in Los Angeles). 
impose the death penalty on African American defendants whose victims were white. ${ }^{249}$

Moreover, the criminal justice system is used today to "solve" problems caused by poverty-drugs and drug-related crime. As Randolph Stone has noted, "[t]he war on drugs has devastated the criminal justice system" as well as "some segments of the AfricanAmerican community."250 Today, "the judicial system has become an assembly line."251 Most defendants do not receive trial by jury or the opportunity to confront witnesses against them. ${ }^{252}$ Because judges are pressured to treat cases summarily, counsel is more important than ever. But effective assistance of counsel is often denied, particularly to the poor or those accused of drug-related crimes. Public defenders handle unmanageable caseloads. ${ }^{253}$ In places without public defenders, poor defendants must rely on court-appointed counsel, who are often required to work pro bono or for token fees. ${ }^{254}$

Once dragged into the criminal "justice" net, the consequences can be devastating, even if police and prosecutors lack sufficient evidence to proceed to trial. Under federal law and many states' laws, if the police suspect that property is related to drugs, they can seize it on grounds as slight as those required for a search warrant::255 probable cause to believe that the property was involved in illegal activities. ${ }^{256}$ Seizure of property makes it more difficult to

248 McCleskey v Kemp, 481 US 279, 286-87 (1987).

${ }^{230}$ Stone, 8 Harv BlackLetter L $J$ at 36 (cited in note 235 ).

251 Id at 34.

${ }^{252}$ For a description of the problem, see Schulhofer, The World \& I at 474 (cited in 245) (As a result of our resource decisions, " $85-90$ percent of criminal convictions are obtained by guilty plea.").

${ }^{253}$ See Stone, 8 Harv BlackLetter I J at 34 (cited in note 235):

Lawyers in our felony trial division [Cook County Public Defender's office] have one hundred pending cases, while those in our Homicide Task Force handle twenty-three pending murder cases each; one-third to one-half of those homicide cases are death penalty cases.

${ }_{254}$ See Schulhofer, The World \& I at $469-75$ (cited in note 245).

${ }^{285}$ See, for example, Walter J. Van Eck, The New Oregon Civil Forfeiture Law, 26 Willamette L Rev 449, 476-78 (1990); Thomas E. Payne, An Introduction to Civil Forfeiture in Mississippi: An Effective Law Enforcement Tool or Cash Register Justice?, 59 Miss L J 453, 463 (1989); Steven L. Kessler, Quo vadis? Assessing New York's Civil Forfeiture Law, 4 Touro L Rev 253 (1988).

258 The federal civil forfeiture provision is at 21 USC $\$ 881$. For a discussion, see Barry Tarlow, Forfeiture Trends, 15 The Champion 42 (Nov 1991); Mark A. Jankowski, Tempering the Relation-Back Doctrine: A More Reasanable Approach to Civil Forfeiture in Drug Cases, 76 Va L Rev 165 (1990); G. Richard Strafer, Civil Forfeitures: Protecting the Innocent Owner, 37 U Fla L Rev 841 (1985); Gerard E. Lynch, RICO: The Crime of Being a Criminal (parts III \& IV), 87 Colum L Rev 920 (1987); Terrance G. Reed, The Defense Case for RICO Reform, 43 Vand L Rev 691, 701-11 (1990); Jeffrey M. Evans, "Civil" For- 
hire counsel either to recover the property or for criminal defense. Given the fiscal crunch facing most law enforcement systems, these statutes create powerful incentives for misuse of seizure without trial.

Using the criminal justice system to battle problems caused by poverty and racism results in a prison population that is half African American men. ${ }^{257}$ There are more African American men in prison than in college. ${ }^{258}$ The incarceration rate in the United States is now the highest known in the world: 426 prisoners per 100,000 population. South Africa is second with a rate of 333 per 100,000 and the Soviet Union third with a rate of 268 per 100,000. Most of the world has much lower rates. For example, Western European rates are $35-120$ per $100,000 .{ }^{259}$

Although poor pregnant addicts cannot find the in-patient medicaid-funded rehabilitation treatment they need, they are increasingly subject to criminal prosecution for delivering drugs to minors. ${ }^{260}$

The misuse of the criminal justice system to address problems of poverty and racism has political effects. People wrongly convicted of many crimes cannot vote in state elections while serving time and in most states even thereafter. ${ }^{261}$ More importantly, keeping the poor impoverished-rather than dealing with poverty effectively-means keeping them" politically ineffective. The poor, disproportionately, do not vote and do not participate in political life. ${ }^{262}$

The protections in the Bill of Rights against misuse of the criminal justice system do not "cause" these problems. But the Bill of Rights does less to guard against misuse of the criminal justice system to combat problems of poverty and racism than it does to guard against misuse of the criminal justice system to silence political dissidents. Furthermore, the misuse of the Bill of Rights to

feitures Under State RICO Laws: A Legislative Attempt to Circumvent the Constitution, 8 Crim Just J 293 (1986).

${ }^{28 z}$ Stone, 8 Harv BlackLetter $\mathrm{L} \mathrm{J}$ at 35 (cited in note 235).

${ }_{258}$ Though one year in prison costs as much as an education at a four-year college. Id.

${ }^{258}$ Mark Mauer, Americans Behind Bars: A Comparison of International Rates of Incarceration 4-5 (The Sentencing Project, 1991). Incarceration rates have been dropping in the Soviet Union. Ten years ago they were estimated to be about $25 \%$ to $100 \%$ higher than current estimates. Id at 4,6 .

${ }^{260}$ See Michelle Oberman, Sex, Drugs, Pregnancy and the Law: Rethinking the Problems of Pregnant Women Who Use Drugs, Hastings L Rev (forthcoming 1992).

${ }^{261}$ Shepard's Lawyer's Reference Manual 575-95 table A-31 (1983) (survey of voter qualifications).

${ }^{262}$ See text accompanying notes $271-73$. 
facilitate the war on drugs has undermined specific constitutional guarantees as applied to poor minorities, especially those accused of drug involvement, by denying them a fair trial with effective assistance of counsel. Thus the general protections of the Bill of Rights against misuse of the system have been effectively destroyed by the drug war for many poor people, who are subjected to assembly-line justice without effective counsel. Finally, the Bill of Rights does not provide any affirmative economic or educational protections for the poor, protections which might ensure that problems of poverty be effectively addressed.

An interpretation of or amendment to the Bill of Rights might lessen these problems by directly addressing the economic and educational needs of the poor and by providing provisions more effective at ensuring justice for all within the criminal justice system. After discussing the "property" right enshrined in the Fifth Amendment, I suggest a number of positive economic and educational rights that we could incorporate in the Bill of Rights. ${ }^{263}$ In addition, the Bill of Rights could include provisions guaranteeing effective assistance of counsel and fair trials. For example, we could interpret effective assistance of counsel as proscribing the seizure of assets used to pay counsel and as requiring reasonable caseloads for public defenders and reasonable fees for court-appointed counsel. ${ }^{264}$ At a minimum, government should be prevented from seizing assets without a trial, and money paid to a lawyer prior to execution of a judgment should be no more coverable than money paid to any other creditor. We could obtain this result by reasonable interpretation of the Fifth Amendment's Takings Clause.

\section{Security Aт Home}

The Fourth Amendment provides that "[ $t]$ he right of the people to be secure in their persons, houses, papers, and effects, against unreasonable searches and seizures, shall not be violated." White male heads of family during the revolution and today face threats to physical security at home from two kinds of intruders: government actors and criminals. The criminal law has been used to protect against the latter, if not always effectively; the Fourth Amendment guards against the former.

\footnotetext{
${ }^{263}$ See text accompanying notes 274-80.

${ }^{264}$ For these and additional suggestions, see Schulhofer, The World \& I at 475 (cited in note 245).
} 
Women, by contrast, face a third major source of physical insecurity within the home: battery and rape by someone who lives in the home-their sexual partners. Yet we have never accorded protection against domestic violence at the level accorded other crimes of violence. The Fourth Amendment does not address domestic violence. The Fourth Amendment protects women against governmental assault, but leaves governments free to treat "domestic" assaults differently from other crimes. Indeed, the criminal codes of many states still deny equal criminal protection to wives who are raped by their husbands. ${ }^{265}$ Although some states have eliminated this distinction, others have extended it to nonmarried cohabitants. $^{266}$

These inequities have political consequences. Women who fear violence redefine themselves as wanting to give what might otherwise be taken away, instead of asserting their own interests, ${ }^{267}$ particularly in a politically effective way. Women who are abused within their most intimate relationships are less able to assert their interests within those relationships. Abused women are unlikely to press strongly for change in the political arena, especially when their interests conflict with the interests of the abuser.

In large part, my criticism is simply that the Fourth Amendment does less for women than it has done for white men, who drafted it. Protected by the criminal justice system from attacks by criminals, they added the Fourth Amendment to protect themselves from governmental intrusion. The Fourth Amendment is much less thorough in providing the protections needed by women. It allows government, police, and prosecutors to treat domestic violence differently from other violence. Indeed, the Constitution allows government to treat marital rape as noncriminal. The Fourth Amendment may have affirmatively made women worse off by giving a constitutional foundation to the notion that a "man's home is his castle."

One can easily imagine improvements in the Bill of Rights from the perspective of violence against women. The Bill of Rights could include an equality standard for sex that would require the state to respond to domestic violence in the same way it responds to other crimes, and to proscribe marital rape. ${ }^{268}$ Such constitu-

${ }^{265}$ See Robin West, Equality Theory, Marital Rape, and the Promise of the Fourteenth Amendment, 42 U Fla L Rev 45, 46-48, 46 n 6 (1990).

${ }^{266}$ See id at $48 \mathrm{n} 11$.

${ }^{26 z}$ See West, 3 Wis Women's $L J$ at, 93-111 (cited in note 51 ).

${ }^{268}$ See generally West, 42 U Fla L Rev 45 (cited in note 265). 
tional provisions would not by themselves revolutionize how police, prosecutors and jurors treat intersexual domestic violence, but they might contribute to changed attitudes. They would, moreover, ensure some of the prerequisites for effective control of domestic violence.

\section{PROPERTY}

The Fifth Amendment provides that "[n]o person shall . . . be deprived of life, liberty, or property, without due process of law; nor shall private property be taken for public use without just compensation." 269 There are a number of problems with this provision from the perspective of minorities and women. First, and most dramatically, at the time the Bill of Rights was adopted in 1789, slaves were property. They were protected as property of others; they could have no property themselves. This provision of the Fifth Amendment was an instrument of oppression for African American women and men.

Second, at the time of the passage of the Bill of Rights, married women could not own or control property. Thus, the Fifth Amendment protected only the property of men and single women.

Third, the protection of "property" meant and means the privileging of existing distributions, no matter how dubious. Consider, for example, the property rights of the newly-freed people vis-a-vis the property rights of their former owners. The fields cleared and cultivated by the freed people belonged to the owners. The buildings and plantations built by the freed people belonged to the owners.

Fourth, while "property" has always included realty and the goods produced by the kinds of labor in which most men spend their working lives, we have never recognized women's reproductive and domestic labor as property. Women's caretaking impedes women's ability to accumulate property in three distinct ways: (1) caretaking itself does not tend to produce property; (2) caretaking tends to limit one's ability to earn property; and (3) caretaking tends to require consumption of property. As a result, women have fewer resources than men and are far more likely to be poor. ${ }^{270}$

Lack of property precludes effective political participation. The poor vote less often, are less politically active, and have fewer

${ }^{269}$ US Const, Amend V.

${ }^{270}$ See, for example, 163 Current Population Reports: Consumer Income: Poverty in the United States: 1987 118-19 (US Bureau of the Census, 1989) (slightly under $11 \%$ of all families are poor, though $34 \%$ of families headed by women are poor). 
resources with which they can influence elections. It is more difficult for the poor to make contributions to candidates likely to represent their interests or to spend money themselves to advance candidates or political positions. Yet the Constitution protects the ability of the rich to spend more politically. ${ }^{271}$ Although seventysix percent of those making over $\$ 50,000$ a year vote, only thirtyeight percent of those making less than $\$ 5,000$ a year vote. ${ }^{272}$ Registration is structured so as to discourage registration by the poor. ${ }^{273}$

Provisions in a Bill of Rights could lessen these problems. A Bill of Rights could provide for positive economic rights, ensuring women economic supports and safety nets as effective as those available to men. Such a Bill of Rights would be more detailed and specific, less elegant, brief, and abstract, than the Bill of Rights we have today. Against this aesthetic loss must be balanced the benefit to women and children, who form the majority of Americans. In addition, a society in which women have more power would be more democratic. Its government would have greater legitimacy. ${ }^{274}$

Affirmative economic rights could include a right to health care under a national and universal health care system (the details of which would be specified by legislation); a requirement of a family allowance (tied to some independent economic indicator, such as a fractional percentage of gross national product); caretaking leave with wage support as part of the unemployment insurance system (with support required at the level generally provided for unemployment compensation); government-financed child care; a requirement that social security benefits be, on average, the same for women and men (within a limited level of tolerance);275 a right to a decent education (with a ban on financing schools through property taxes and a requirement that per pupil expenditures be uniform throughout the United States); ${ }^{276}$ and a requirement that breadwinners and homemakers be treated the same with respect to

${ }^{271}$ Buckley v Valeo, 424 US 1 ( (1976).

${ }^{272}$ Garry Wills, 'New Votuhs', NY Rev Books 3, 3 (Aug 18, 1988).

273 Id.

${ }^{274}$ See Linda Gordon, What Does Welfare Regulate? 55 Soc Res 609, 629 (1988).

${ }^{275}$ For a discussion of the many structural problems in the social security system, see Mary E. Becker, 89 Colum L Rev 264 (cited in note 17).

${ }^{276}$ In New Jersey, where the state supreme court has interpreted the state Constitution as banning differential school funding levels based on local property taxes, "per-pupil expenditures are still $\$ 2,880$ in poor districts and $\$ 4,029$ in wealthy districts." Hewlett, When the Bough Breaks at 58 (cited in note 181). See generally id at 56-61, 246-49. 
all substantive standards for disability. ${ }^{277} \mathrm{~A}$ ban on abortion should be seen as a taking (of women's reproductive labor) for government purposes without compensation. ${ }^{278}$ The Bill of Rights should also include a right to abortion, fully paid by the state, in light of (inter alia) the economic consequences of childbearing for women.

Further, the Bill of Rights should make family law a matter within the control of the national government and not the states. Gender relations in the family are of primary importance for a just society. ${ }^{279}$ Setting a framework for just relationships should be a priority for national government; living within such a framework should be a prerogative of national citizenship. ${ }^{280}$

Like other provisions of the Bill of Rights, the Takings Clause of the Fifth Amendment does much more for men than for women, favoring men's productive labor over women's reproductive labor. The Due Process Clause of the Fifth Amendment also favors men's experiences, by enshrining as the "rule of law" a legal system developed by and for elite white men. In the next Section, I examine this provision and contrast it with the jury provisions, which now provide for the participation of all in applying the laws developed by the few.

\section{Due Process and the Jury Provisions}

The Fifth Amendment provides for "due process" before any person is deprived of "life, liberty, or property." Seventh Amendments provide for a jury trial in criminal and civil cases. ${ }^{282}$ The "due process" guaranteed by the Fifth Amendment thus entitled its framers, mostly elite white men, to the procedures

\footnotetext{
${ }^{277}$ Social Security has different substantive disability standards for homemakers and breadwinners. See Becker, 89 Colum L Rev at 269 (cited in note 17).

${ }^{278}$ In making this point, I do not suggest that women's reproductive ability should be treated in all respects like alienable property rights. Indeed, I think it a mistake to commodify women's bodies by creating a market for their reproductive labor. For a discussion of the problems with a market approach, see Margaret Jane Radin, Market-Inalienability, 100 Harv L Rev 1849 (1987); Cass R. Sunstein, Neutrality in Constitutional Law (with Special Reference to Pornography, Abortion, and Surrogacy), 92 Colum L Rev 1 (1992). I am merely stating that government should not be able to take women's reproductive labor without compensation by banning abortion. Women's reproductive labor should, however, be inalienable.

279 See generally Susan Moller Okin, Justice, Gender, and the Family (Basic, 1989).

${ }^{280} \mathrm{I}$ am indebted to Hendrik Hartog for this idea.

${ }^{281}$ US Const, Amend V.

${ }^{282}$ US Const, Amends VI and VII. In civil cases, the right applies "where the value in controversy shall exceed twenty dollars." US Const, Amend VII.
} 
and substantive rules of a legal system developed by and for people like themselves. At that time, women and African Americans could not participate as either lawyers or judges.

Today, the legal system remains one developed by and for propertied white men, with strong, built-in, conservative tendencies, in the form of well-developed substantive rules combined with rules favoring precedent. ${ }^{283}$ As I have described, ${ }^{284}$ the overwhelming majority of legislators and judges continue to be men. "Due process" continues to mean something quite different for propertied white men and other groups.

The Sixth Amendment provides that "[i]n all criminal prosecutions, the accused shall enjoy the right to a speedy and public trial, by an impartial jury. . . ."285 At the time the Bill of Rights was enacted, neither women nor slaves were allowed on juries. As early as 1880 , however, the Supreme Court held that states could not overtly exclude African Americans from juries under the Fourteenth Amendment. ${ }^{286}$ But African Americans were effectively excluded throughout the South until relatively recently. Juries were drawn from voter rolls which-until the 1960s-included few African Americans. And in the North as well as the South, African Americans could be excluded on the ground of race from any particular jury prior to the Supreme Court's 1965 Fourteenth Amendment decision in Swain v Alabama ${ }^{\mathbf{2 8 7}}$ and its 1986 decision in Batson $v$ Kentucky. ${ }^{288}$ Since these cases, it has been unconstitutional to exclude African Americans or other racial minorities either from jury lists or from a particular jury because of race.

A more limited set of rules has developed with respect to sex. ${ }^{289}$ The Supreme Court found overt limitations on women's presence in jury pools to be unconstitutional under the Fourteenth Amendment in $1975 .{ }^{290}$ But several lower courts have refused to

${ }^{283}$ See, for example, Lois G. Forer, Unequal Protection: Women, Children, and the Elderly in Court (Norton, 1991) (retired judge discussing the many ways in which legal rules developed by white male judges adversely affect women, children, and the elderly).

${ }^{284}$ See text accompanying notes 8-14.

${ }^{285}$ US Const, Amend VI.

${ }^{286}$ Strauder $v$ West Virginia, 100 US 303, 310 (1880).

${ }^{287} 380$ US 202 (1965).

288476 US 79 (1986).

${ }^{289}$ See generally Shirley S. Sagawa, Batson v Kentucky: Will It Keep Women on the Jury?, 3 Berkeley Women's L J 14 (1987/1988); Note, Sex Discrimination in the Voir Dire Process: The Rights of Prospective Female Jurors, 58 S Cal L Rev 1225 (1985).

${ }^{290}$ Taylor $v$ Louisiana, 419 US 522 (1975). See also Duren v Missouri, 439 US 357 (1979). The Supreme Court has held that jury exclusions violate the Sixth Amendment only when capital sentencing occurs. See Lockhart v McCree, 476 US 162 (1986). 
hold unconstitutional the exclusion of women from jury panels even if the exclusion is on the basis of sex. ${ }^{291}$ Thus, the right to trial by a jury selected without discrimination on the basis of sex remains unavailable to women. Further, minority women remain without effective protection on the basis of race and sex. ${ }^{292}$

I suggest three changes to the Bill of Rights in the areas of due process and jury selection. First, in civil cases there should be the same protections against sex discrimination in jury selection as for race. ${ }^{293}$ Second, women and minorities should be protected from sex or race discrimination by prosecutors in challenging jurors in criminal cases. Indeed, we might ban all peremptory challenges by prosecutors. ${ }^{294}$

Third, judges and legislators, as well as jurors, should represent the population. We require that juries be representative with respect to race and somewhat representative with respect to sex, but have no constitutional provisions regarding judges or legislators. This is so even though the law developed and applied by judges and legislators is all the process that is "due" in any dispute before a jury or a judge. For any group other than white men, who is on the bench or in the legislature is more important than who is on the jury.

The Bill of Rights could require that judges represent the population with respect to sex and race. The African National Congress (ANC) Draft Bill of Rights includes a provision that "the judiciary shall be transformed in such a way as to consist of men and women drawn from all sectors of . . society." ${ }^{295}$ The Bill of Rights could provide that women's representation in legislatures at appro-

${ }^{293}$ See, for example, United States v Hamilton, 850 F2d 1038, 1042 (4th Cir 1988); State v Olivera, 534 A2d 867, 870 (RI 1987). See also State v Gilmore, 511 A2d 1150, $1159 \mathrm{n}$ 3 (NJ 1986). Even when women are on jury panels, they tend to be less influential than the men on the jury. See Nancy S. Marder, Gender Dynamics and Jury Deliberations, 96 Yale L J 593, 597-98 (1987).

292 Minority women should, one would think, be entitled to more, not less, protection because of their dual disadvantages. See generally, Judy Scales-Trent, Black Women and the Constitution: Finding Our Place, Asserting Our Rights, 24 Harv CR-CL L Rev 9 (1989). See also Kimberle Crenshaw, Demarginalizing the Intersection of Race and Sex: A Black Feminist Critique of Antidiscrimination Doctrine, Feminist Theory and Antiracist Politics, 1989 U Chi Legal Forum 139.

${ }^{293}$ See Edmonson v Leesuille Concrete Co., Inc., 111 S Ct 2077, 2079 (1991) (race can not be basis for excluding juror in civil case). Structural changes may also be needed to accommodate women's different approaches to dispute resolution. See Laura Gaston Dooley, Sounds of Silence on the Civil Jury, 26 Valp U L Rev 405 (1991).

284 See, for example, Albert W. Alschuler, The Supreme Court and the Jury: Voir Dire, Peremptory Challenges, and the Review of Jury Verdicts, $56 \mathrm{U}$ Chi L Rev 153, 232 (1989).

${ }^{285}$ ANC, A Bill of Rights for a Democratic South Africa Art 14, $₹ 7$ (cited in note 191). 
priate levels is of prime importance in a democracy, and authorize Congress to enact a Voting Rights Act for Women. Such an act could offset the political problems women face as a result of freedoms we all value, such as freedom of religion and speech. If we had separate voting districts for women and men, women would be represented in legislatures in rough proportion to their presence in the population. ${ }^{296}$ Women tend to hold elective office in higher numbers in multi-member districts, ${ }^{297}$ under proportional representation, ${ }^{298}$ and with internal party quotas for women candidates. $^{299}$ Our parties already have internal sex-based quotas for their national committees, and the Democrats have experimented with quotas for convention delegates. Our parties could be encouraged to experiment with such quotas by government funding tied to the number of women running in open elections. ${ }^{300}$

\section{ConCLUSION}

The Bill of Rights serves the interests of those most like its drafters: relatively elite white men who tend to own more than their share of "property." Other groups-particularly women, the poor, and people of color-have fewer of their needs addressed by this revered document. I have shown three kinds of problems with the provisions of the Bill of Rights.

My major point has been critical: the Bill of Rights does less for other groups than it does for those in the class of propertied white men; often it perpetuates or even magnifies social inequities rather than eliminating them. When this happens, the Bill of Rights becomes part of the problem, rather than the solution. Second, the Bill of Rights is often an impediment to reform; this is

${ }^{206}$ This is more or less the result with respect to racial minorities under the remedial scheme of the Voting Rights Act. See, for example, Voting Rights Act Extension, S Rep No 97-417, 97th Cong, 2d Sess 1000-10 (1982).

${ }^{297}$ See, for example, Susan Welch and Albert K. Karnig, Correlates of Female Office Holding in City Politics, $41 \mathrm{~J}$ Pol 478, 486-87 (1979); Janet Clark, et al, Women as Legislative Candidates in Six States, in Janet A. Flammang, ed, Political Woman 141, 154 (Sage, 1984).

298 See Anne Phillips, Engendering Democracy 80-83 (Pennsylvania, 1991). There are disadvantages to proportional representation. Proportional representation, like divided government, tends to mean weak government. See Arend Lijphart, Democracies: Patterns of Majoritarian and Consensus Government in Twenty-One Countries 107-26, 150-68 (Yale, 1984).

299 Phillips, Engendering Democracy at 83-89 (cited in note 298).

${ }^{300}$ For example, the national parties could be given so much in federal funds for each woman in an open election for the House, double that amount for open Senate races, and triple that amount for open governor races. 
particularly true for the First Amendment's Free Speech Clause and the Second Amendment insofar as it prevents gun control legislation. Third, the problems ignored or even perpetuated by the Bill of Rights have political consequences for women and other outsider groups. More fundamentally, the Bill of Rights has done too little to ensure that women, a majority group, can exert their interests effectively in the political system.

I have suggested a number of changes to the individual provisions of the Bill of Rights, changes that we could implement either as interpretations or as amendments. These changes would make the Bill of Rights more responsive to the needs of women and other outsider groups and should produce a more effective democratic structure.

In this Conclusion, I add three more general criticisms. First, part of the problem is that the Constitution contains no strong provision on sex discrimination. If such a provision were in the Bill of Rights, it might help judges balance other rights, such as free exercise of religion, against the right of women to social equality. Such a provision should be a right to substantive, not formal, equality. ${ }^{301}$ In addition, as in the ANC Draft Bill of Rights, ${ }^{302}$ the Bill of Rights should ban discrimination on the basis of sexual orientation, both because lesbian and gay people are a vulnerable group needing protection, ${ }^{303}$ and because compulsory heterosexuality is a form of discrimination against women..$^{304}$

${ }^{301}$ See, generally Catharine A. MacKinnon, Toward a Feminist Theory of the State 215-49 (Harvard, 1989); Catharine A. MacKinnon, Reflections on Sex Equality Under Law, 100 Yale L J 1281 (1991).

${ }^{302}$ See ANC, A Bill of Rights for a Democratic South Africa, Art $7 \S 2$ (cited in note 191) ("Discrimination on the grounds of gender, single parenthood, legitimacy of birth or sexual orientation shall be unlawful."). The European Human Rights Commission has interpreted the European Human Rights Convention as banning punishment for at least private homosexual acts between consenting adults. See Glendon; Rights Talk at 146-58 (cited in note 20).

However, I realize that a judicially enforced abstract right to sex equality would not do much for women. The drive for its adoption would drain scarce resources from more effective strategies for change. See, for example, Rosenberg, The Hollow Hope (cited in note 16); Becker, 1987 S Ct Rev 201 (cited in note 16). I do not, therefore, suggest we should seek such a right at the present time. I merely mention that, in a Constitution anywhere near ideal, we would have a substantive sex equality provision.

${ }^{303}$ See Bruce A. Ackerman, Beyond Carolene Products, 98 Harv L Rev 713, 730-31 (1985); Janet E. Halley, The Politics of the Closet: Towards Equal Protection For Gay, Lesbian, and Bisexual Identity, 36 UCLA L Rev 915, 916 n 5 (1989).

sor See Sylvia A. Law, Homosexuality and the Social Meaning of Gender, 1988 Wis L Rev 187, 187 (1988); John Stoltenberg, You Can't Fight Homophobia and Protect the Pornographers at the Same Time-An Analysis of What Went Wrong in Hardwick, in Dorchen Leidholdt and Janice G. Raymond, eds, The Sexual Liberals and the Attack on 
Second, the Bill of Rights and other provisions of the Constitution have created a structure posing obstacles to the implementation of the sorts of economic support systems and safety nets present in every other North Atlantic nation. Mary Ann Glendon makes this point powerfully and persuasively in her most recent book. ${ }^{305}$ Several features of our Constitution have reinforced the individualism so dominant in our culture: the absolutist wording of individual rights in the Bill of Rights; the failure of the Bill of Rights to include any positive economic rights; and the focus of both the Constitution and the Bill of Rights on limited government as the guarantor of liberty. Given these elements in our constitutional structure, it is not surprising that initial attempts at social legislation in this country were declared unconstitutional as violations of the Contracts Clause, a variation on the property right protected in the Fifth Amendment. ${ }^{306}$ We abandoned this approach during the New Deal, ${ }^{307}$ but by then the United States was far behind the Continent in providing economic support systems. The gap persists today. ${ }^{308} \mathrm{Had}$ we no written constitution so that a Lochner era never happened we might live today in a more just society. ${ }^{309}$

My third and last general criticism has been made before by Jennifer Nedelsky, among others. Because the Framers focused on protection of private property as the key to liberty, they devised a "democratic" anti-majoritarian governmental structure. They saw the major problem of democracy as the "problem of majority oppression." 310 The solution was to create barriers to ordinary people's participation, including multiple levels of government and

Feminism 184 (Pergamon, 1990); MacKinnon, Toward a Feminist Theory of the State at 57 (cited in note 301); Adrienne Rich, Compulsory Heterosexuality and Lesbian Experience, in Rich, Blood, Bread, and Poetry 23 (Norton, 1986).

${ }^{305}$ See Glendon, Rights Talk at 106-08 (cited in note 20). For a discussion of the symbolic power of the Constitution, see Hendrik Hartog, The Condition of Aspiration and "The Rights That Belong to Us All", 74 J Amer Hist 1013 (1987).

${ }^{306}$ See, for example, Lochner v New York, 198 US 45 (1905).

${ }^{307}$ West Coast Hotel Co. v Parrish, 300 US 379 (1937) (overruling Lochner).

${ }^{308}$ Glendon, Rights Talk at 32-46 (cited in note 20). For a brief discussion of economic supports in Europe, see Sheila B. Kamerman and Alfred J. Kahn, What Europe does for Single-Parent Families, 93 Pub Int 70 (Fall 1988).

${ }^{309}$ It is also possible that we would live in a fascist dictatorship. For an argument that a constitution should include provisions "designed to work against precisely those aspects of a country's culture and tradition that are likely to produce harm through that country's ordinary political process," see Cass R. Sunstein, On Property and Constitutionalism, 17 U Chi L Econ Working Paper No 3 (2d series 1991).

${ }^{310}$ Jennifer Nedelsky, Private Property and the Limits of American Constitutionalism: The Madisonian Framework and its Legacy 220-22 (Chicago, 1990). 
rule by a distant elite. ${ }^{311}$ In addition, the Constitution limited directly the ability of less-distant state governments to experiment with the basic structure of the economy. ${ }^{312}$

Seeing the problem of democracy as the problem of majority oppression of the propertied minority is particularly inappropriate from the perspective of women. Women are a majority of the population, who have never controlled or even exercised their proportionate share of influence. Surely we should regard men's domination of positions of power within government as at least $a$ problem of democracy in light of women's ability to vote during the last seventy-one years.

We should consider whether other governmental structures and electoral systems would be more democratic. Three independent branches of government minimize governmental action, preserving the status quo. A requirement of coordination among three independent branches is countermajoritarian and conservative. Action is easier in parliamentary systems which integrate the legislative and executive power. We also should consider other electoral systems, such as the ones suggested above. ${ }^{313}$

These are not all pragmatic proposals for change. Members of our legislative bodies are not likely to change the way the game is played when they have won under existing rules. My point is that our governmental structure is not ideal from the perspective of women, other outsider groups, or, indeed, democracy. We could imagine better structures, and many are in place in some parts of the world. We should not be exporting ours, as is, to Eastern Europe.

How should we assess a constitutional structure or a Bill of Rights? I suggest that we should consider, along with other factors, how well the system facilitates women's political participation, poverty rates (especially for women and children), physical safety, and incarceration rates. Measured by these standards, our constitutional system must be found wanting.

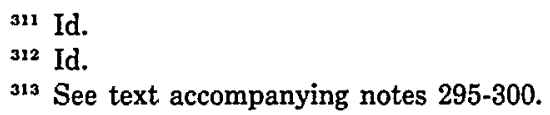


$$
\text { . }
$$ 